\title{
Review \\ Composite Membrane Dressings System with Metallic Nanoparticles as an Antibacterial Factor in Wound Healing
}

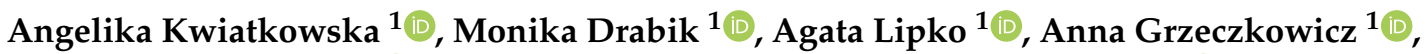 \\ Radosław Stachowiak $^{2}$, Anna Marszalik ${ }^{2}$ and Ludomira H. Granicka ${ }^{1, *(\mathbb{D})}$
}

1 Nalecz Institute of Biocybernetics and Biomedical Engineering, Polish Academy of Sciences, Trojdena 4 St., 02-109 Warsaw, Poland; ankwiatkowska@op.pl (A.K.); mdrabik@ibib.waw.pl (M.D.); alipko@ibib.waw.pl (A.L.); agrzeczkowicz@ibib.waw.pl (A.G.)

2 Institute of Microbiology, Faculty of Biology, University of Warsaw, Miecznikowa 1 St., 02-096 Warsaw, Poland; r.stachowiak@uw.edu.pl (R.S.); anna.marszalik@biol.uw.edu.pl (A.M.)

* Correspondence: lgranicka@ibib.waw.pl; Tel.: +48-(22)-592-59-00

\section{check for}

updates

Citation: Kwiatkowska, A.; Drabik,

M.; Lipko, A.; Grzeczkowicz, A.;

Stachowiak, R.; Marszalik, A.;

Granicka, L.H. Composite Membrane

Dressings System with Metallic

Nanoparticles as an Antibacterial

Factor in Wound Healing. Membranes

2022, 12, 215. https://doi.org/

$10.3390 /$ membranes12020215

Academic Editors: Enrico Drioli and Rebecca Green

Received: 21 December 2021

Accepted: 9 February 2022

Published: 13 February 2022

Publisher's Note: MDPI stays neutral with regard to jurisdictional claims in published maps and institutional affiliations.

Copyright: (C) 2022 by the authors. Licensee MDPI, Basel, Switzerland. This article is an open access article distributed under the terms and conditions of the Creative Commons Attribution (CC BY) license (https:// creativecommons.org/licenses/by/ $4.0 /)$.

\begin{abstract}
Wound management is the burning problem of modern medicine, significantly burdening developed countries' healthcare systems. In recent years, it has become clear that the achievements of nanotechnology have introduced a new quality in wound healing. The application of nanomaterials in wound dressing significantly improves their properties and promotes the healing of injuries. Therefore, this review paper presents the subjectively selected nanomaterials used in wound dressings, including the metallic nanoparticles (NPs), and refers to the aspects of their application as antimicrobial factors. The literature review was supplemented with the results of our team's research on the elements of multifunctional new-generation dressings containing nanoparticles. The wound healing multiple molecular pathways, mediating cell types, and affecting agents are discussed herein. Moreover, the categorization of wound dressings is presented. Additionally, some materials and membrane constructs applied in wound dressings are described. Finally, bacterial participation in wound healing and the mechanism of the antibacterial function of nanoparticles are considered. Membranes involving NPs as the bacteriostatic factors for improving wound healing of skin and bones, including our experimental findings, are discussed in the paper. In addition, some studies of our team concerning the selected bacterial strains' interaction with material involving different metallic NPs, such as AuNPs, AgNPs, $\mathrm{Fe}_{3} \mathrm{O}_{4} \mathrm{NPs}$, and CuNPs, are presented. Furthermore, nanoparticles' influence on selected eukaryotic cells is mentioned. The ideal, universal wound dressing still has not been obtained; thus, a new generation of products have been developed, represented by the nanocomposite materials with antibacterial, anti-inflammatory properties that can influence the wound-healing process.
\end{abstract}

Keywords: wound healing; membrane dressings; bacteria; metallic nanoparticles as an antibacterial factor

\section{Introduction}

The clinical and economic burden of wound management increases globally every year. The trend is the most evident in developed countries with aging societies, where many patients suffer from civilization diseases. It is well known that comorbidities influence the effectiveness of the applied therapies, worsen injury healing, and lead to hardly curable chronic wounds. Despite significant efforts to reduce the risk of complications, the problem of difficult wound healing is still a major challenge for modern medicine. According to data gathered for the calendar year 2014 by Nussbaum and co-workers, based on the Medicare 5\% Limited Data Set, total spending estimates ranged from USD 28.1 to USD 96.8 billion for all wound types in the United States [1]. On the other hand, The Guest Group estimates that the cost of wound care in the United Kingdom was at $£ 4.5$ to $£ 5.1$ billion in 2012 [2]. Generally, it is estimated that around 1.5-2 million people are 
suffering from both acute and chronic wounds across Europe [3]. It should be mentioned that prolonged therapies resulting from ineffective wound healing not only influences the budgets of national health institutions but also cause the deterioration in the quality of patients' lives [3]. In order to reduce the economic burden on the system, several optimization programs have been introduced. For example, continuous improvement of health care procedures and training of medical personnel improves clinical practice and, thus, significantly lowers the therapy costs, providing benefits not only for patients and health care workers but also for the entire system [4]. On the other hand, a no less important aspect of wound healing therapy is optimal treatment using comprehensive dressings and therapeutics supporting the process [3]. Thus, it cannot be surprising that scientists worldwide have performed intensive studies on novel materials of specific parameters that could be potentially employed in wound dressings. It turns out that the achievements of nanotechnology may prove helpful. In recent years, it has become clear that nanomaterials have introduced a new quality in wound healing, opening the way to personalization and better adjustment of the dressing to the type of wound, environmental agents, or factors resulting from the patient's burden with comorbidities. Furthermore, it was proven that the application of nanomaterials in wound dressing promotes injuries healing. Another important aspect connected to injuries care is bacteria participation, which becomes less clear-cut as knowledge of the wound healing process grows. To improve the effectiveness of wound therapy and consider the increasing multidrug resistance of bacteria, novel materials like nanoparticles are gaining popularity as antimicrobial factors.

This paper presents the subjectively selected nanomaterials used in wound dressings, including the metallic nanoparticles, and refers to the aspects of their application as antimicrobial factors. The literature review was supplemented with the results of our team's research on multifunctional new-generation dressings containing nanoparticles. The review discusses wound healing multiple molecular pathways, mediate cell types, and the affecting agents. Moreover, the categorization of wound dressings and some materials and membrane constructs applied in wound dressings are presented. The nanomaterials for wound dressings are presented, including the involvement of metallic nanoparticles. The mechanism of the antibacterial function of nanoparticles is discussed. Moreover, nanoparticles' influence on selected eukaryotic cells is mentioned. Membranes involving NPs as the bacteriostatic factor for improving wound healing of skin and bones, including our experimental findings, are discussed. Some of our team's studies concerning the selected bacterial strains' interaction with material involving different metallic NPS, such as AuNPs, AgNPs, $\mathrm{Fe}_{3} \mathrm{O}_{4} \mathrm{NPs}$, and $\mathrm{CuNPs}$, are presented. Neither the ideal, universal wound dressing nor the perfect dressing material has yet been designed. Therefore, a new product generation of nanocomposite materials with antibacterial and anti-inflammatory properties supporting wound healing has been developed.

\section{The Process of Wound Healing}

\subsection{Mechanism}

Wound healing refers to a replacement of missing and devitalized cellular and tissue structures in living organisms [5]. Although the mechanism of the process is well known, discrepancies still appear in its characterization due to the complexity and dynamic course of its action. According to contemporary concepts, the human wound healing process consists of the four main stages: hemostasis, inflammation, proliferation, and remodeling with scar tissue formation [6-8]. On the other hand, the previous models do not distinguish hemostasis but treat it as a part of the inflammatory phase [9-11]. Moreover, some authors used maturation or resolution names instead of the remodeling or granulation names or instead of proliferation when describing the distinct stages.

Wound healing success depends on the appropriate course of all successive stages. These phases have integrated with each other and occur in the specified time frames. Any aberrancies or interruptions disturb this highly programmed and precise process, resulting in complications and delays in the healing. In the worst case, chronic wounds might appear. 
During the hemostasis and inflammation stages, debris and bacteria are removed, exudates are coagulated, and blood is clotting. Simultaneously, the release of reactive oxygen species (ROS), proteases, growth factors (such as FGF-fibroblast growth factor, EGF-epidermal growth factor, TGF- $\beta$ - transforming growth factor, and PDGF-platelet-derived growth factor [12]), and cytokines are triggered. Then, the epithelial cells migrate to the wound site (chemotaxis), and the proliferation phase can start, during which granulation tissue is formed, and angiogenesis and EMC secretion occur. Finally, wound contraction and reepithelization follow in the remodeling phase, resulting in scar tissue formation. As the appropriate environment must be formed, the whole wound healing process requires a long time to complete. The last stage can last from dozens of days (21 days) to one year. In Figure 1, we present the cellular and bio-physiologic events occurring during the normal wound-healing process, which Gao and di Petro described, whereas Figure 2 illustrates wound restoration stages together with their main cellular components.

\section{Phase Cellular and Bio-physiologic Events}
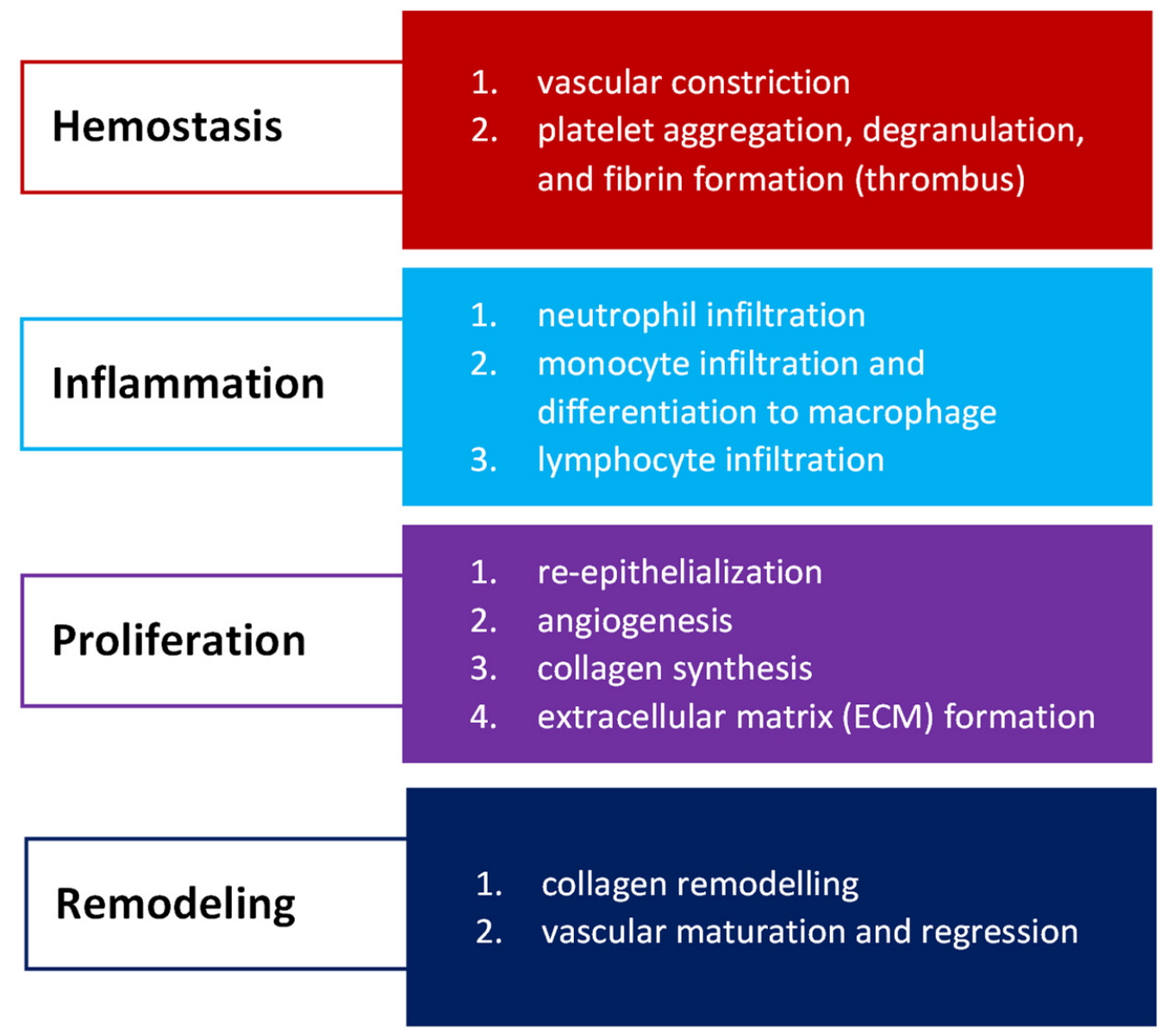

Figure 1. Cellular and bio-physiologic events occurring during the normal wound-healing process described by Gao and di Petro [12]. 

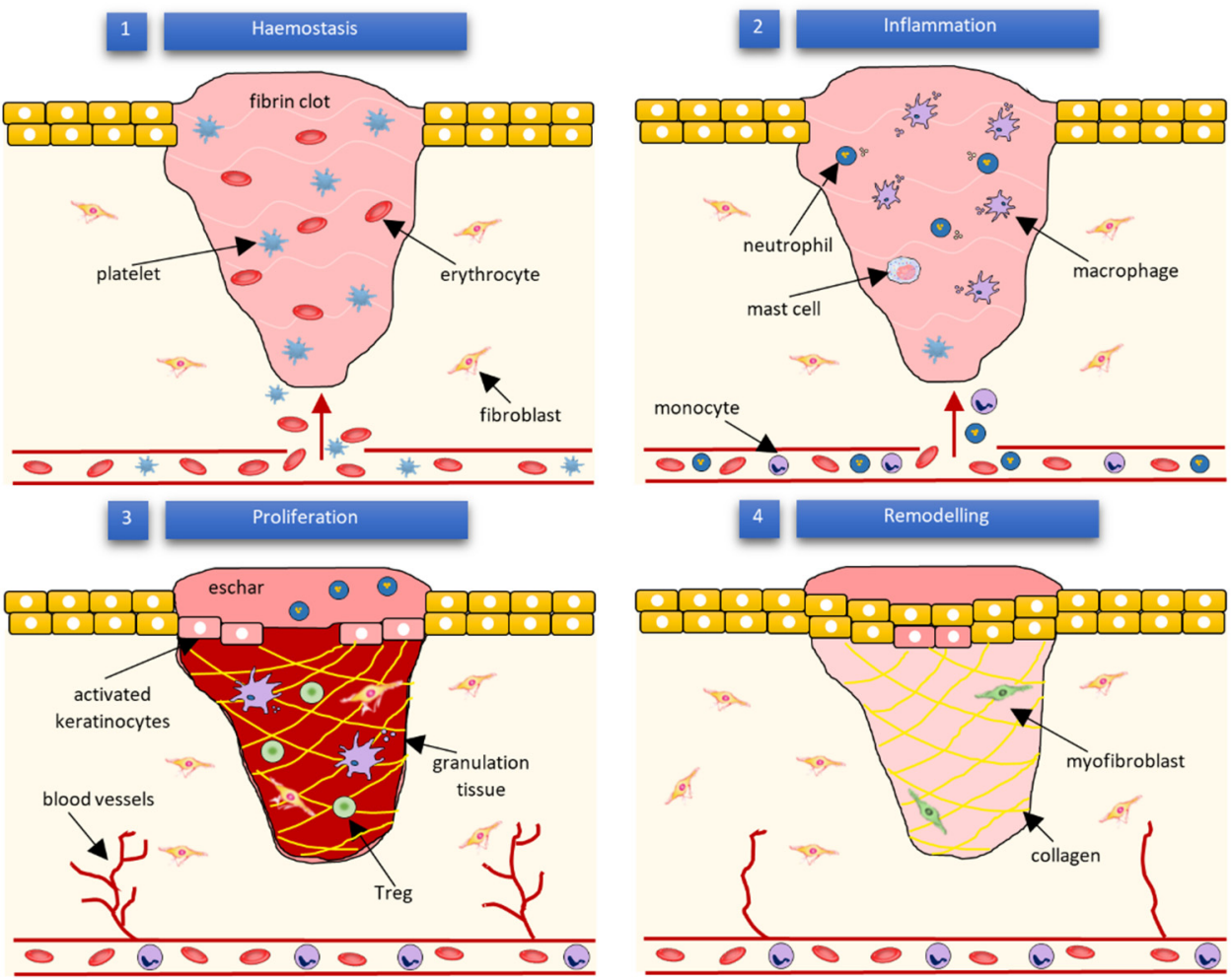

Figure 2. Subsequent phases of wound healing and their main cellular components according to Wilkinson and Hardman [13].

Multiple molecular pathways and cell types mediate wound healing. Among other cells, the blood cells such as neutrophils, macrophages, and T-lymphocytes play a crucial role in the process. Neutrophils release ROS, and proteases as well are responsible for the removal of microorganisms, necrotic material, and cell debris occurring in the wound area [12]. On the other hand, macrophages produce cytokines [14,15], induce and clear apoptotic cells [16], and, after the phenotypic transition to reparative mode, promote the proliferation phase $[17,18]$. According to some authors, it is worth mentioning that efferocytosis (the process of apoptotic cells' removal), which helps impede inflammation, might be a crucial function in the entire wound healing process [19]. The T-lymphocytes' function is not yet completely understood. They are heavily involved in the inflammation [20] and re-epithelialization phases [6]. Nosbaum and co-workers proved that Foxp3-expressing regulatory $\mathrm{T}$ cells (Tregs) attenuate inflammation associated with injuries and facilitate cutaneous wound healing using the epidermal growth factor receptor (EGFR) pathway [21]. Other types of cells taking part in wound celling are fibroblasts, endothelial, and stem cells. The endothelial cells support the formulation and growth of new tissue [22]. For example, together with fibroblasts, they promote capillary growth [12]. Moreover, they are essential during hemostasis regulated by the dynamic balance between thrombocytes and endothelial cells, fibrinolysis, and coagulation [22,23]. On the other hand, fibroblasts support the collagen production and formulation of granulation tissue. Furthermore, they are responsible for producing the extracellular matrix components-glycosaminoglycans and proteoglycans [12]. Finally, it is considered that the contractile fibroblasts, termed myofibroblasts, mediate wound physical contraction $[9,24]$. Stem cells (SC) enhance wound healing by releasing growth factors and through paracrine signaling. They also influence the regeneration of damaged tissues $[10,25]$. Especially, adult stem cells like bone-marrow (BM)-derived cells (BMDCs) and epidermal stem cells have recently gained researcher attention. Epidermal stems give rise to the keratinocytes, which then re-epithelialize the wound [12]. Mesenchymal SC (MSC), present in the bone marrow, can differentiate into several cell types, among which fibroblasts, keratinocytes, osteoblasts, chondrocytes, and 
adipocytes can be enumerated [26]. On the contrary, hematopoietic SC (HSC), also found in bone marrow, gives rise to endothelial progenitor cells (EPCs) that are involved in neovascularization [27]. The presented list of cells contributing to wound healing is not complete—several other cell types are also involved—but it clearly shows the complexity of the process.

\subsection{Factors Affecting Wound Healing}

The wound healing process depends on many individual and environmental factors. For example, the patient's age weakening the body's innate ability to regenerate [28], ischemia $[29,30]$, or microbial infections often limit therapy's effectiveness. Generally, two types of agents affecting wound healing can be highlighted: local factors directly influencing the wound characteristics and systemic ones related to the patient's overall state affecting the healing process. Age, gender, stress, ischemia, chronic diseases, level of sex hormones, nutrition, underlying comorbidities, or addictions (alcoholism) are examples of factors from the second category, whereas infections, venous sufficiency, and oxygenation [31] can be categorized as local agents [12]. Some authors distinguish additional subcategories. The diagram in Figure 3 shows the division inspired by the work of the Beyene group [32].

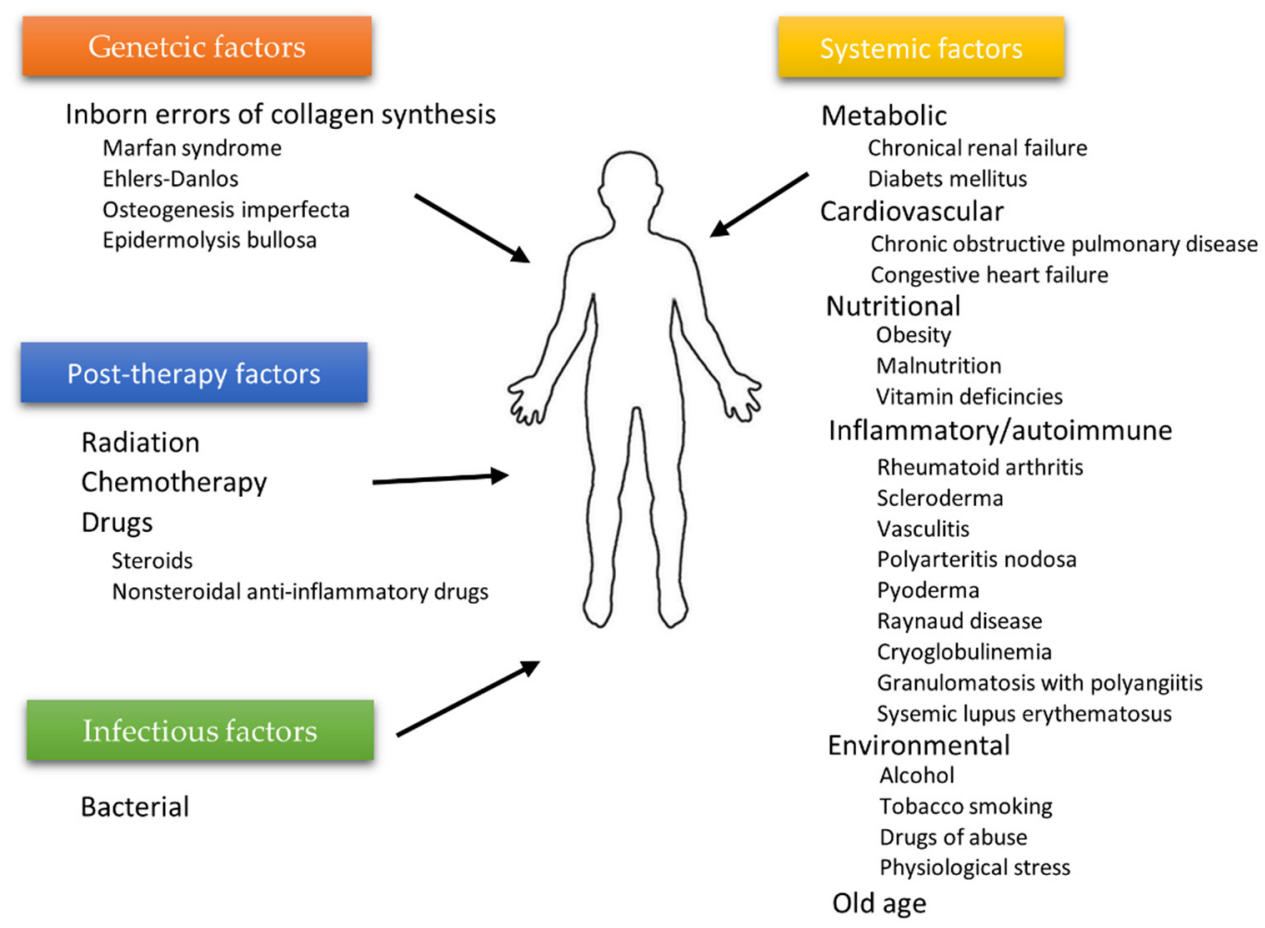

Figure 3. Factors affecting wound healing according to Beyene et al. [32].

Usually, a few factors are present simultaneously, leading to the increased impairment of wound healing. For that reason, the elimination of some of them can significantly improve the quality of treatment. Modern medicine applies many different techniques, reducing the action of unfavorable local and systemic factors. For example, hyperbaric oxygen therapy (HBOT) is applied to decrease the influence of chronic tissue hypoxia. Unfortunately, even though this method is adequate, it is not commonly available [33]. On the other hand, by using simple methods, the influence of inadequate nutrition, which worsens the ability to heal wounds, can be easily leveled [12]. Similarly, the bacterial infection risk can be overcome if the appropriate wound care is applied. Nonetheless, some factors affecting wound healing still represent a significant challenge in therapy. Especially, the agents related to the civilization diseases are problematic, as it is difficult to immediately improve the overall condition of the organism, which has been weakened by years of neglect $[34,35]$. 
More and more authors underline the significance of nutrition in the process of appropriate wound healing. Deficiencies of nutrients and malnutrition can reduce the ability to heal injures $[12,36]$. For that reason, contemporary treatment is becoming more holistic and includes the administration of therapeutics that not only work locally but also support the functioning of the entire organism. For example, arginine supplementation applied as an adjuvant treatment in wound care can achieve great results, as the metabolic demand for this amino acid increases under serving stress [24]. Arginine is indispensable during injury and periods of intensified growth because it influences the immune system and stimulates wound healing [37]. Similarly, it has been demonstrated that oral glutamine supplementation can increase the level of mature collagen and reduce the tendency of wounds to break [38]. On the other hand, achieving and maintaining the appropriate glucose level is crucial for diabetic patients' therapy, as Arnold and Barbul reported [36]. Finally, the significance of protein doses in wound healing cannot be overlooked either. Protein-calorie malnutrition decreases T-cell function, drops phagocytic activity, depreciates antibody levels, and decreases wound tensile strength. As a result, the body loses its ability to protect the wound against infection [36]. The list of elements influencing healing is much longer. Micronutrients, vitamins, or fatty acids need to be present in sufficient amounts to facilitate the process [36]. In addition, the deficiency of individual elements might affect the healing pathways [12]. The supporting effect of proper nutrition during the therapy was shown perfectly in the Hayman group studies. The team's clinical research indicated that the inclusion of high-energy supplements enriched by nutrition improved the healing of the pressure ulcer [39]. The next factor affecting wound healing is physiological stress. Studies have shown that stress significantly delays the process of healing by impairing the regular immunity at the injury site [40,41] Furthermore, it might cause unhealthy behaviors on psychological grounds (starting from anxiety and depression and ending with unfavorable habits such as alcoholism and abuse of drugs) that can be, on their own, detrimental to the wound healing process [12,42]. Advancing age is a known risk agent in reducing wound healing effectiveness [43]. This factor should be considered carefully, especially since the elderly population (over 60 years old) enlarges globally [12,43]. In recent decades, significant progress has been made in molecular and cellular biology, which has allowed scientists to broaden the knowledge of cell function loss with age. Many studies point to the impaired stress response of senescent cells as the leading cause of their dysfunction $[28,30]$. Moreover, several therapies reducing age-related wound healing impairment have been tested. For example, studies have shown that exercise can support cutaneous wound healing by stimulating anti-inflammatory response, decreasing the levels of pro-inflammatory cytokines in the injured tissues [44]. Nonetheless, with today's level of development in medicine, it is not yet possible to eliminate the factors associated with the natural aging of cells. On the contrary, it is an entirely different matter for limiting the possibility of wound infections. The literature shows clinical examples of chronic wounds closed with success by lowering the bacterial count. Among others, perirectal wounds arising from fistulae or abscesses, pin tracts, and injuries with significant depth/surface area ratio were ultimately healed by applying this approach $[28,45]$.

\subsection{Bacteria Participation in Wound Healing}

It should be noted that not all bacteria contribute to the wound healing process equally. Pathogens impede curative therapy [46], whereas commensal skin microorganisms positively affect treatment by regulating the innate immune response [47,48]. Modern studies indicate that the presence of bacteria promotes wound healing. Microorganisms can produce proteolytic enzymes, influencing the proteases' release from neutrophils and supporting wound debridement [49]. However, for wounds that reach critical levels of bacterial colonization, the healing capacity decreases significantly, which is related to the metabolic load imposed by microorganisms [50]. Undoubtedly, skin microbiota composition analysis and monitoring are critical for developing novel treatment methods/wound dressings [51,52]. The excess of bacteria needs to be reduced to improve the effective- 
ness of chronic and acute wound therapy, but the balance of skin microbiota should be preserved simultaneously. For these reasons, and considering the increasing antibiotic resistance of bacteria, novel materials such as nanoparticles gain popularity as factors playing antimicrobial roles.

\section{Wound Care Management}

The development of effective wound treatment is one of the main goals of modern medicine. According to Gupta and co-workers, wound management is a holistic cycle, encompassing the procedures related to the care of patients with wounds, starting from diagnosis and ending in follow-up. The steps of that ongoing process include wound recognition and characterization, risk assessment, selection of the optimal treatment, preparation of wound bed, monitoring, and taking practical actions depending on the observation results and evaluation of the effectiveness of the applied therapy [53]. Furthermore, effective wound care management can shorten the treatment and lower its costs, particularly in the case of chronic wounds therapy [54]. Therefore, medical personnel must pay special attention to adapting existing protocols to the individual needs of specific patients $[55,56]$. The appropriate dressing selection fitting the wound characteristic manifests such an approach $[54,57]$. In Figure 4, the model of a cycle of wound assessment and decision-making as to procedures is shown.

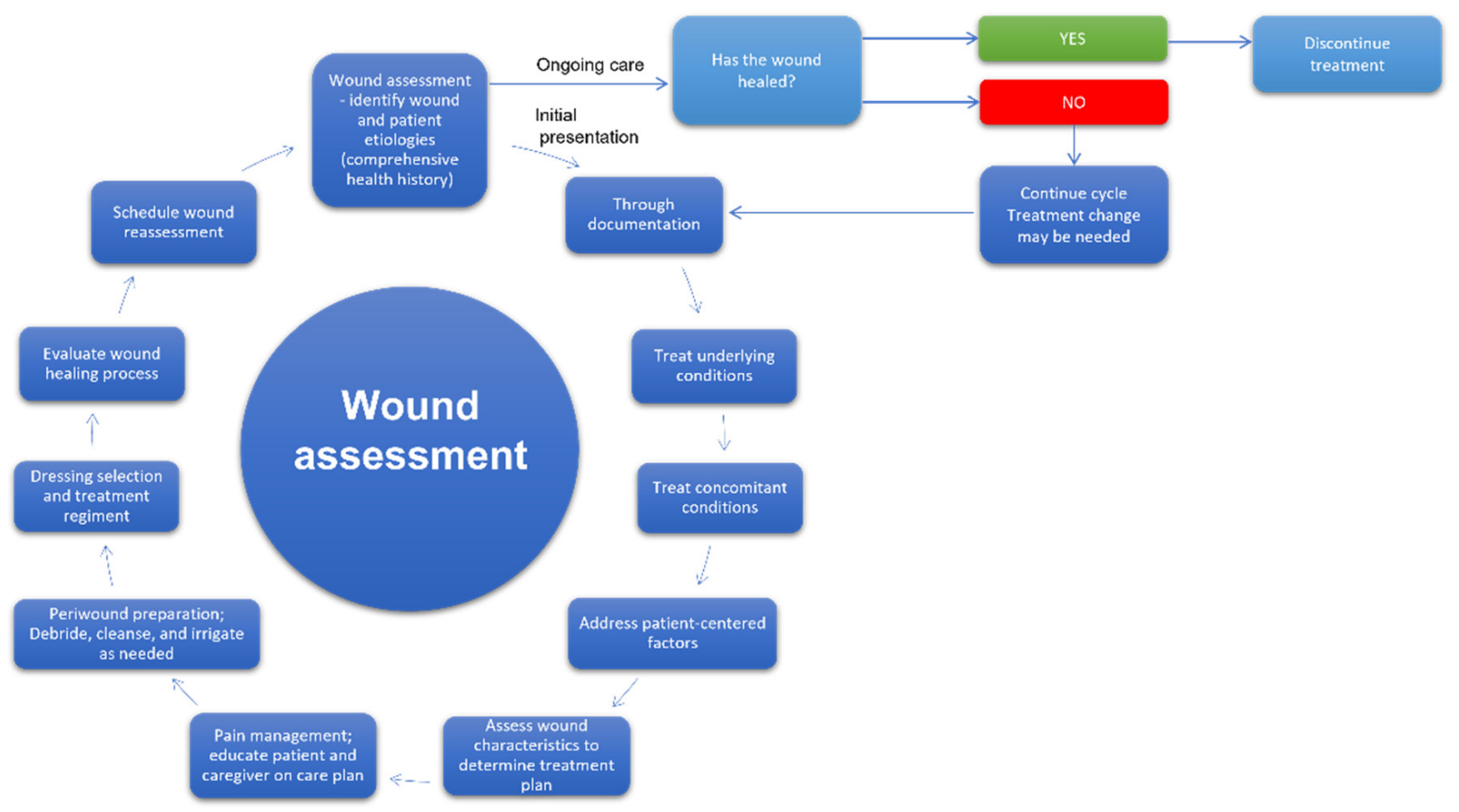

Figure 4. The cycle of wound assessment and decision on procedures $[53,58]$.

\subsection{Wound Dressings}

The ideal, universal wound dressing does not exist. Some materials can be excellent for one type of injury, but that does not mean they will work for others. Each time, factors such as the profoundness of the wound or the exudates amount need to be considered before deciding on the applied dressing [59]. It is worth mentioning that the optimal wound dressing should be biocompatible, easy to apply, cheap, and, often, hypoallergenic [11,54]. Furthermore, it has to maintain a moist environment [60,61], ensure gas permeability [62], and simultaneously enable the extract of excess exudate from the injury area [59]. Furthermore, it ought to balance skin microbiota while protecting against infections [63]. The long list of the necessary wound dressing requirements generates the need for continuous research on the novel materials used in modern systems for injury healing. 
Considering the wide range of wound dressing applications, it cannot be surprising that different classifications are used to categorize them [7]. First of all, taking into account the usage time, we can distinguish primary (directly applied to the wound) and secondary (employed to cover primary ones) dressings $[64,65]$. The second category relates to the interaction with the biological material (tissue) and embraces inert (passive) and bioactive (interactive) dressings. According to Weller and Sussman, passive dressings might be subclassified into absorbing and non-absorbing, whereas interactive dressings are grouped as absorbing, non-absorbing, and moisture donating [65]. Passive dressings have limited usage due to the permeability to bacteria and the high risk of adhesion to the wound. However, they are successfully applied for minimal and low-exudating wounds (like minor burns and simple, clean superficial wounds), mainly as a secondary dressing. They can also serve as primary dressings over skin grafts [65]. Moreover, the modern generation of passive dressings is characterized by better properties than their predecessors. For example, gauze dressing based on tulle and paraffin provides a waterproof layer protecting the injury. However, it should be noted that this type of cover is still not permeable for vapor and exudation; thus, it might cause maceration with prolonged usage [66]. Conversely, technologically advanced bioactive dressings interact with the wound to facilitate healing. Their main advantage is to provide moisture conditions in the wound area using the environment ensured by the organism. Bioactive dressings contain biologically active agents supporting wound healing, not rarely of antimicrobial function (e.g., growth factors, insulin, antibacterial compounds). They are made of different materials, including synthetic and natural polymers (e.g., elastin, hyaluronic acid, collagen, alginate), playing the role of active compounds or supporting biologically active factors [67]. The first line of bioactive dressings includes plasters immediately available for subacute and acute wounds, commonly used in clinical practice; the second line refers to unconventional (e.g., antimicrobial) dressings employed for complex chronic wounds. Among the examples of the first group are alginate [68-70], hydrogel [71-74], semi-permeable film [65], hydrocolloid [75-77], foam [78-80], and hydroactive [81,82] dressings [65]. In the second category, interactive hydrofibre [83], wet [65], silicone [84,85], honey [86-88], capillary wicking [89], hypertonic saline [90], silver [91-94], cadexomer iodine [95,96] dressings, and zinc paste bandages [97-99] are placed.

The last division references the material and technology applied to produce dressings; traditional, biomaterial-based, and artificial dressings are distinguished. Traditional plasters and bandages are based on cotton and gauze elements. They are treated as classic dressings, as they were used for centuries. Traditional dressings usually do not ensure appropriate moisture and must be changed frequently [57,100]. The biomaterial-based category includes allografts, xenografts, and tissue-engineered derivatives. This group includes skin substitutes, facilitating wound healing and closure of wounds by replacing skin function [101-106]. On the other hand, membrane, gel, spray, composites, foam, and film-based dressings are examples of the third type.

\subsection{Modern Wound Dressing Materials and Nanomaterials}

It is impossible to fulfill the increasingly stringent wound dressing requirements (e.g., biodegradability, biocompatibility, and bioabsorbability) based only on classically used materials like rayon, woven, and non-woven fibers of cotton, polyesters, or rubber. Therefore, it cannot be surprising that different materials of unique properties and forms are applied in modern dressings. Especially polymers, of both synthetic and natural origin, garner great attention in the field; among the naturally occurring polymers employed in dressing production, chitosan [107], hyaluronic acid [108], keratin [109], gelatin, starch [110], silk fibroin [111], heparin [112,113], collagen [114], sericin [115], sodium alginate [116,117], zein [118], and konjac glucomannan [119-121] can be enumerated [122,123]. On the other hand, polyvinyl alcohol (PVA) [110], polylactic acid (PLA) [124], polyacrylic acid (PAA) [110], polyethylene glycol (PEG) [125], polycaprolactone (PCL) [126], and 
polyvinylpyrrolidone (PVP) [127] are examples of synthetic polymers applied for that purpose [128].

One of the most popular materials used in wound dressings is collagen. The role of this protein in wound healing is well described. The clotting cascade, resulting in a fibrin clot that stops the initial bleeding, is activated due to collagen exposure during the injury [129]. The mechanism by which coagulation allows for hemostasis in four phases of wound healing [130] is complex. The process occurs through a series of clotting factors using the extrinsic pathway (activated through tissue factor released by endothelial cells after external damage) and the intrinsic pathway activated through exposed endothelial collagen [131]. In the inflammation phase, Collagen I and IV fragments can be mediators of inflammation by acting as potent chemoattractants for neutrophils, enhancing phagocytosis and immune responses and modulating gene expression [129]. Inflammation is a critical step in the normal wound healing process and drives the proliferation of fibroblasts, which synthesize collagen and extracellular matrix (ECM) [129,132]. In 2019, the global collagen dressings market was valued at approximately USD 926 million [133,134]. Bovine origin collagen dominates the markets, and its composites with antimicrobial function have been the main subject of interest $[133,134]$. Many formulations of collagen dressings in the form of powder, gels, and films have been designed [135-139]. Another popular dressing material is chitosan, which might serve as the potential drug carrier because of its good biodegradability and biocompatibility and the potential to be modified by various chemical modifications to obtain desired properties. In addition, chitosan has a filmforming ability, and it is characterized by low immunogenicity. Finally, it has outstanding antibacterial and antifungal properties $[140,141]$. The latest example of chitosan application in wound dressing might be the 3D printed chitosan scaffolds proposed by the Hafezi group [142]. In turn, another material, nanoscale hyaluronic acid (HA), can improve cell adhesion on bone biomaterials and can provide significant mechanical reinforcement. It is one of the many biopolymers applied to prepare wound dressings, exhibiting several beneficial effects such as the decline in inflammatory processes and regulation of tissue remodeling [143,144]. It can be noted that the materials can be combined with each other and/or factors to ensure the expected properties. For example, the hydrogel formulation based on an antimicrobial peptide (AMP), epsilon-poly-l-lysine (EPL), and catechol, which was crosslinked via mussel-inspired chemistry between the amine and phenol groups, was reported. In vitro studies showed that EPL-catechol hydrogels possess remarkable antimicrobial and antibiofilm properties toward multidrug-resistant $A$. baumannii after three days of culture. In addition, a cytotoxicity study with the clonal mouse myoblast cell line (C2C12) revealed the good biocompatibility of this hydrogel [145]. Moreover, a sponge material prepared from a solution containing chitosan-polyvinyl alcohol emulsion with added polyhexamethylene guanidine hydrochloride in a homogeneous medium using lyophilization technology was explored. The applied material was reported to exhibit antibacterial function against multidrug-resistant $A$. Baumanni after $24 \mathrm{~h}$, among others, allowing it to obtain an optical density significantly lower for the experimental group than for the control (untreated material). However, the visualization of bacterial cells within the bandage material was not presented [146]. Nevertheless, among the ready-made dressings on the market, the two hydrogels are mainly applied: alginate and collagen. In dressings based on collagen, their degradation rate and mechanical properties can be influenced by electrostatic cross-linking with chitosan or stabilization by hydrogen bonding with sugars or polyphenols [147]. Table 1 presents ready-made dressings using alginate and collagen as the primary substrates.

The intensive development of nanotechnology observed in recent decades opened up an entirely new perspective for the field of wound dressings. Currently, nanostructured systems (materials with at least one external dimension measuring between 1 and $100 \mathrm{~nm}$ [148]) of various types are commonly applied as a part of the dressing to support wound healing. Among the different nanostructures used in the dressings, nanocolloids, nanocapsules, nanospheres, nanoemulsions, and nanoparticles can be listed [11]. 
Table 1. Materials based on collagen and alginate in the form of commercially available dressings.

\begin{tabular}{ll}
\hline \multicolumn{1}{c}{ Material } & \multicolumn{1}{c}{ Commercially available dressings } \\
\hline collagen/chitosan & Collagen \\
collagen/chitosan/glycosaminoglycans & Kollakhit [149] \\
collagen/glycosaminoglycan (chondroitin-6-sulphate) & Kollakhit-Bol [149] \\
collagen/oxidized regenerated cellulose & Integra (Integra Life Sciences) [150] \\
collagen/oxidized regenerated cellulose/AgNPs & Promogran (Systagenix Wound Management) [151] \\
collagen/tricalcium phosphate $\beta-\mathrm{Ca}_{3}\left(\mathrm{PO}_{4}\right)_{2}$ & Promogran Prisma [152] \\
& Vitoss granules (Orthovita) [153,154] \\
\hline & Alginate \\
\hline & Aquacel Ag ${ }^{\circledR} ;$ \\
alginate/AgNPs & Biatain ${ }^{\circledR}$ Alginate Ag; \\
& CuraFoam ${ }^{\mathrm{TM}}$ AG Silver Foam Dressing; \\
& DynaGinate ${ }^{\mathrm{TM}}$ AG Silver Calcium Alginate Dressing; \\
& Dynarex ${ }^{\circledR}$ DynaFoam ${ }^{\mathrm{TM}}$ AG Bordered Silver Foam Dressing [155] \\
\hline
\end{tabular}

Nanocolloids are composed of discrete entities of compounds (of the size of 1 to $100 \mathrm{~nm}$ ) highly suspended/dispersed within a fluid medium (e.g., demineralized water). Nanocolloids occur in particulate form, wherein these particles might be organic or inorganic (e.g., non-ionic metal nanoparticles) in the crystalline or amorphous state. Nonetheless, the entities might also be formed by non-covalent molecular aggregates [156]. In addition, scattered particles may exhibit collective behavior. The particles are usually positively charged and have excellent electrical conductivity. In wound dressings, nanocolloids are used as antimicrobial agents, as they can penetrate eukaryotic and prokaryotic cells due to the perpetual Brownian motion [11]. However, some authors point to their potential cytotoxicity, limiting their usage on a mass scale [157].

Nanocapsules (NEs) consists of an oily or aqueous core surrounded by a distinctive polymeric membrane [158]. Their key advantage is the capability of encapsulation of active factors within their structure and their gradual release in time, which provides the controlled delivery. In addition, nanocapsules, applied as an element of the wound dressing, might increase the penetration level of active factors into deeper dermis layers, wherein the effectiveness of the compounds can decrease [159]. For example, an exciting example of the application of nanocapsules in wound healing therapy was reported by Guartinello and co-workers. The authors developed an antibacterial wound dressing composed of $\mathrm{pH}$-responsive human serum albumin/silk fibroin nanocapsules immobilized onto cotton/polyethylene terephthalate (PET) blends loaded with eugenol [160].

Nanospheres (NSs) are tiny, uniform spherical systems built of a fixed porous biodegradable or nonbiodegradable polymeric core onto which biologically active agents (drugs, amino acids, plasmid DNA) can bind [161-163]. Thanks to this structure, active substances can be evenly distributed throughout the core, which improves their stability, biocompatibility, and general pharmaceutical properties and provides the possibility of the sustained, controlled release of loaded compounds [11]. Among the polymers, the one most often used to compose nanospheres, chitosan, polylactic acid (PLA), gelatin, and polylactide/glycolide might be mentioned [161]. Active factors are released from the nanosphere by diffusion, showing excellent drug-release profiles, especially for watersoluble agents [164]. The release time depends on the composition of the polymeric matrix, its loading capacity, and nanosphere size. Moreover, environmental factors like polymer core erosion, enzymatic degradation, or hydrolysis, causing the cleavage of polymer bounds and diffusion of the physically captured active substances, also influence the efficiency of the release process [164]. NSs are usually applied to entrapped hydrophilic or hydrophobic drugs $[162,163]$. The route of administration is compound-depended. For each substance, its intravenous targeting effect and controlled-release effects as well as its subcutaneous or intramuscular sustained-release, needs to be considered [161,165]. An 
example of the usage of nanospheres in wound dressing is ZnO-loaded chitosan/poly(vinyl alcohol)/acacia gum nanosphere-based nanocomposite thin films obtained through electrospraying [166]. Another interesting concept of dressing combining antimicrobial and regenerative properties was proposed by Müller et al. The authors designed three-dimensional (3D) electrospun poly(D,L-lactide) (PLA) fibermats into which nanospheres, formed from amorphous calcium polyphosphate (polyP) nanoparticles (NP) and encapsulated retinol ('retinol/aCa-polyP-NS'nanospheres (NS)), had been incorporated [167].

Nanoemulsions (NEs) are homogenous, colloidal particulate forms in the submicron size range (droplet size of maximum $1000 \mathrm{~nm}$; usually between 100 and $500 \mathrm{~nm}$ [168]) acting as carriers of drug molecules [159]. They are typically thermodynamically metastable oilin-water $(\mathrm{o} / \mathrm{w})$ systems composed of emulsifier-coated oil droplets dispersed within an aqueous medium used to deliver hydrophobic active substances [169]. However, the multiple emulsions systems can be designed. Another example is water-in-oil (w/o) emulsions, where water droplets are dispersed in oil. These systems are applied for the delivery of hydrophilic compounds. More complex arrangements are water-in-oil-inwater (w/o/w) and oil-in-water-in-oil (o/w/o) emulsions [170]. Nanoemulsions can be formulated in many different forms, such as sprays, creams, liquids, and foams [171]. They show good fluidity and decreased viscosity [172]. Furthermore, the small-sized droplets have a greater surface area, providing better absorption of active agents [171]. According to Aswathanarayan and co-workers, NEs, in contrast to microemulsions, are not affected by physical and chemical variations, including temperature and $\mathrm{pH}$ [170] a completely different view than that presented by Chime Group [168]. Insufficient comprehension of the mechanisms of the biological fate of nanoparticles after digestion and the potential toxicity of engineered nanoemulsions limit their application in the food industry and medicine [170]. Additionally, the next great challenge connected with the popularisation of NEs' usage is the high costs of their production, requiring investments in special equipment (e.g., homogenizers) [168]. Nevertheless, the NEs have still been explored, e.g., nanoemulsion of clove oil was reported to present significant wound healing effects in rats compared to pure clove oil [173].

Nanoparticles (NPs) used in wound treatment can be divided into two groups: nanoparticles served as delivery systems for active compounds and nanoparticles of specific intrinsic properties supporting injuries healing [11]. These are composed of metallic (silver, gold, copper, and zinc NPs), metal oxide (copper oxides, ferroxides), or nonmetallic (fullerenes and carbon NPs, polymer nanoparticle (PNP), lipid-based NPs, ceramic NPs) nanomaterials.

Metal nanoparticles such as silver, gold, and zinc are usually integrated into a wound dressing to provide antimicrobial properties and facilitate wound healing. Due to their unique structure, they are characterized by the increased surface-to-volume ratio, which lowers their concentration in the dressing [159]. Among the factors influencing the biological behavior of nanoparticles, their chemical structure and heterogeneity, porosity, and hydrolytic stability can be enumerated. The abovementioned characteristics determine how the nanoparticles interact with other biomolecules, and thus indirectly affect their biodistribution [11].

Generally, it is assumed that nanoparticles exhibit low cytotoxicity [11]. However, some scientists raise the issue of the mechanism of nanoparticles accumulation in live organisms, which is not well studied yet [174-177] especially, that nanoparticle toxicity is related to their structure (dimension and architecture) and characteristics (particle surface charge described by zeta potential, value of polydispersity index, surface functionalization) [178]. Most often, the smaller the particles, the greater their biological activity. Similarly, the particle surface charge determines its capability for penetrating cellular barriers and its capacity for receptor binding [179]. According to Auffan and co-workers, the potential cellular toxicity of nanoparticles depends on their chemical stability [180].

Nanomaterials employed in wound dressings can occur in the form of individual nanoparticles or as nanocomposites. Moreover, coatings and scaffolds are also often used. 
There are two main approaches for nanomaterial usage in wound healing therapies: (1) nanomaterials of necessary properties are incorporated into polymers, or (2) nanocarriers are applied for the encapsulation of the other materials, mainly active agents [181]. Nanoelements are embedded in support materials to improve their antimicrobial properties (metallic nanoparticles), stiffen the dressing structure (e.g., fullerenol), mimic the extracellular structure (nanoscafolds), or support cell growth (nanofibers). As a result, the designed dressing materials can be customized and adjusted to the specific wound types. On the other hand, the possibility of closing the active agent in nanoelements provides the opportunity for targeted delivery of biologically active substances (growth factors, drug). Barroso and co-workers have collected the most popular therapeutics (bioactive agents, drugs, oligonucleotides, nitric oxide, and plasmid DNA) encapsulated within the various types of nano-sized carriers. The division which they proposed is shown in Table 2.

Table 2. Various therapeutics delivered by nanocarriers in wound healing therapies, according to Barroso et al. [181]. Key to symbols: NPs-Nanoparticles.

\begin{tabular}{|c|c|c|c|c|c|}
\hline \multirow{2}{*}{ Nanocarrier } & \multicolumn{5}{|c|}{ Therapeutic } \\
\hline & Bioactive Agent & Drug & Oligonucleo-tide & Nitric Oxide & Plasmid DNA \\
\hline Ceramic NPs & & $x$ & & $x$ & \\
\hline Dendrimers & & & $x$ & & \\
\hline Gold NPs & & $x$ & & & \\
\hline Iron oxide NPs & & & & $x$ & \\
\hline Liposomes & $x$ & $x$ & $x$ & & \\
\hline Micelles & & $x$ & & & \\
\hline Polymeric NPs & $x$ & $x$ & & & $x$ \\
\hline Silver NPs & & $x$ & $x$ & & $x$ \\
\hline Solid Lipid NPs & $x$ & $x$ & & & \\
\hline
\end{tabular}

Another critical aspect of nanomaterial usage in wound healing is to fit the applied material to the appropriate phase of the process. For example, gold nanoparticles usually serve as an anti-inflammatory agent; however, the studies show that AuNPs also support epidermal re-epithelization through the proliferation of the keratinocytes. In turn, carbon nanotubes properties are used during inflammation, whereas iron oxide NPs are most effective during proliferation and remodeling stages. Therefore, the developed dressing should be constructed to emphasize the advantages of different materials. For example, the nanoelements needed in the later phases of wound healing should be placed in the inner layers of the multilayer dressing. Various therapeutics delivered by nanocarriers in wound healing therapies are presented in Table 3.

Table 3. Various therapeutics delivered by nanocarriers in wound healing therapies, according to Barroso et al. [181]. Key to symbols: NPs-Nanoparticles.

\begin{tabular}{|c|c|c|c|c|}
\hline \multirow{2}{*}{ Nanocarrier } & \multicolumn{4}{|c|}{ Phase } \\
\hline & Hemostasis & Inflammation & Proliferation & Remodeling \\
\hline $\begin{array}{l}\text { Carbon } \\
\text { nanotubes }\end{array}$ & & $x$ & & \\
\hline Ceramic NPs & $x$ & $x$ & $x$ & \\
\hline Copper NPs & & & $x$ & \\
\hline Dendrimers & & & $x$ & \\
\hline Gold NPs & & $x$ & $x$ & \\
\hline Iron oxide NPs & & & $x$ & $x$ \\
\hline Liposomes & & $x$ & $x$ & \\
\hline Micelles & & & $x$ & \\
\hline Nanoceria NPs & $x$ & $x$ & $x$ & $x$ \\
\hline Polymeric NPs & $x$ & $x$ & $x$ & \\
\hline Silver NPs & & $x$ & $x$ & \\
\hline Solid Lipid NPs & & & $x$ & \\
\hline
\end{tabular}


To summarize, many different nano-based systems were designed and tested to be used in wound therapies, especially as a part of modern wound dressings. Each of them has various properties and might be applied to achieve specific characteristics of the resulting material. For example, nanofibers can replace artificial dermal analogs, as they provide favorable conditions for cell-drug integration and cell attachment. In contrast, nanoscaffolds imitate the properties of the extracellular matrix by mimicking the fibrous nature and nanoscale features of skin elements. In turn, inorganic particles serve as antibacterial agents and support wound healing. On the other hand, polymeric particles' properties are beneficial in the controlled release of active agents and protect the drug from degradation by wound proteases. Finally, liposomes ensure a moist environment on the wound surface and provide sustained drug release. Similarly, other lipid particles (like nanostructured lipid carriers or solid lipid NPs) favor the controlled release of active factors and secure the administration's versatility [181]. The final decision on applying a nano-based system depends on the wound-healing phase, the expected therapeutic effect, injury characteristics, and drug parameters (required dose, mechanism of action).

\section{Nanoparticles and Mechanism of Antibacterial Function}

The broad spectrum of antibacterial activity of the nanoparticles makes them an inherent element of biomaterials. For example, using the NPs in modification of tantalum oxide coatings by attaching silver nanoparticles (2.61\% concentration), it was found that AgNPs improve material antibacterial properties against Staphylococcus epidermidis while maintaining the function of (rat bone mesenchymal stem cells) tested in the system [182]. In addition, modification of polyvinyl chloride endotracheal tubes with gold nanoparticles shows bacteriostatic activity against Listeria monocytogenes [183]. Another example of the usage of silver nanoparticles is an attempt to reduce complications related to the application of intravenous ports. However, it should be noted that [184] clinical trials comparing polyurethane AgTive ${ }^{\circledR}$ silver-impregnated or unmodified central intravenous catheters found that silver-impregnated catheters did not reduce the incidence of catheter-related infections spreading downstream of the bloodstream compared to standard intravenous central catheters. This theory is also confirmed by the meta-analysis conducted in 2014 by Chen et al. [185].

The mechanism of the antibacterial action of soft transition metal nanoparticles, including silver and gold, is not well understood. Some researchers suggest that the antibacterial activity of silver nanoparticles may be due to the damage they cause to the cell membrane. They observed that the accumulation of AgNPs (5-10 nm) on the cell wall of Escherichia coli leads to perforation, which results in the loss of integrity of the bacterial outer membrane. In addition, biomolecular and structural damage has been reported in lipopolysaccharide and phosphatidylethanolamine [186]. NPs can penetrate the cytoplasm of the bacterial cell and damage intracellular structures [187]. It was noted that AuNPs could penetrate Streptococcus pneumoniae bacteria, generating the formation of a spherical cytoplasmic structure called the inclusion body of gold nanoparticles, the composition of which remains unknown [188]. Another mechanism of antimicrobial activity results from the oxidation of soft transition metal nanoparticles in contact with water, which leads to the release of ions [189]. The bacteriostatic effect of the released ions is closely related to their interaction with the thiol groups of enzymes and proteins associated with the cell wall, disrupting the respiratory chain and the function of the bacterial cell wall [190]. Inhibition of major proteins in the respiratory chain (e.g., cytochrome b) causes an increase in reactive oxygen species (ROS) such as hydrogen peroxide $\left(\mathrm{H}_{2} \mathrm{O}_{2}\right)$, hydroxyl $(\mathrm{OH}-)$, and peroxide $\left(\mathrm{O}_{2}-\right)$, radicals inside the cell, which leads to oxidative stress and protein and nucleic acids damage, with subsequent bacterial death [172,189,191-194]. The DNA damage includes nuclear fragmentation [195] or physical attachment of the NPs to the DNA [196]. In addition, the exposure of bacteria to NPs causes genomic changes such as gene upregulation, downregulation, and expression levels in dependence on bacterial strain and nature of NPs, e.g., AgNPs regulate 309 genes in E. coli [197]. Subsequent studies show that affecting P. melaninogenica and A. pyogenes 
AgNPs is mainly related to oxidative and nitro-oxidative stress induced by ROS generation, which results in increased leakage of dehydrogenase and NO [198].

\section{Nanoparticles' Interaction with Eukaryotic Cells}

Regarding the interaction of NPs with eukaryotic cells, reports present the assumption that NPs cross the cell membrane and mitochondria [175,199]. Similar to the mechanism of toxicity for bacterial cells, silver nanoparticles toxicity is connected to the overproduction of ROS affecting the respiratory chain of mitochondria, DNA damage [200], and apoptosis [201].

As far as skin penetration is concerned, it has been found, among others, on a rodent model that AuNPs of $15 \mathrm{~nm}$ diameter aggregate in deeper layers of the skin, while larger AuNPs (about 100-200 nm) reach only the epidermis and derma [202]. In turn, particles with an iron core with a diameter equal to or less than $20 \mathrm{~nm}$ can reach the living epidermis of human skin [203].

Moreover, there are reports that AgNPs coated with polyvinylpyrrolidone 10-50 nm in size showed, at TEM assessed penetration studies, that their presence in the stratum corneum and electrothermal atomic absorption spectroscopy allowed for their penetration into the water compartment [204]. Attention should be paid to the possibility of endocytosis of NPs by eukaryotic cells, which may be disadvantageous in dressings, although it is desirable for drug delivery systems functioning. There are some reports of NPs' interaction with different eukaryotic cells, for example, lung cell lines A549 and 95D.

It was found that AuNPs are endocytosed by lung tumor cells, and, additionally, the influence of AuNPs on the invasiveness of lung cancer cells in vitro was proven. AuNPs with a diameter of $5 \mathrm{~nm}$ can stop the growth of A549 cells (human lung cancer cell line) but at the same time increase the invasiveness of these cells. The AuNPs at $10 \mathrm{~nm}$ diameter increases the invasiveness of 95D cells (non-small cell lung cancer). Such effects are not observed for larger NPs with 20-40 nm dimensions. Increased invasiveness may be associated with increased expression of metalloproteinase-9 in the matrix and the intracellular adhesive molecule-1. This result suggests that metalloproteinase- 9 and intracellular adhesion Protein-1, the key invasiveness modulators, are regulated by AuNPs [205]. Moreover, some authors examined the influence of $\mathrm{CuO}, \mathrm{Fe}_{3} \mathrm{O}_{4}$, and $\mathrm{Fe}_{2} \mathrm{O}_{3} \mathrm{NPs}$ on A549 cells. However, a high variation among nanoparticles concerning their ability to cause toxic effects was observed; $\mathrm{CuO}$ nanoparticles were most potent regarding cytotoxicity and DNA damage. No or low toxicity was observed for iron oxide particles $\left(\mathrm{Fe}_{3} \mathrm{O}_{4}, \mathrm{Fe}_{2} \mathrm{O}_{3}\right)$ [206].

The assessment of the influence of copper oxide nanoparticles (CuONPs) on human laryngeal epithelial cells proved that induction of cytotoxic influence is associated with the increase in reactive oxygen species [207]. Moreover, it was demonstrated that the CuNPs showed higher toxicity than their oxide nanoparticles CuONPs in HL60 cells [208].

AgNPs are applied in orthopedic implants because of their antibacterial properties and possible enhancement of mineralization of osteoblast or osteoblast-like cells [209-211].

Nevertheless, some authors demonstrated that AgNPs $<100 \mathrm{~nm}$ inhibited the differentiation and mineralization of osteoblast-like cells MG-63 due to uptake and retention of AgNPs. Furthermore, cytotoxic effects of low-dose AgNPs on MG-63 cells persisted even after termination of exposure in a 72-h experiment [212].

Our team studied, on human bone cells hFOB and fibroblasts HDF, the internalization of AuNPs of about $10 \mathrm{~nm}$ diameter, which were part of nanocomposite elements of the dressing developed for cooperation with the bone-skin interface. However, the internalization of NPs occurred and no cytotoxic effect against the hFOB and HDF cells was observed. Moreover, it was found that the participation of fullerenol within the membrane layer stops the internalization of AuNPs by human osteoblasts hFOB [213].

Designing material for cooperation with eukaryotic cells is essential to balance bacteriostatic and cytotoxic activity.

Our team examined the selected bacterial strains' interaction with material involving different metallic NPS, such as AuNPs, $\mathrm{AgNPs}, \mathrm{Fe}_{3} \mathrm{O}_{4} \mathrm{NPs}$, and CuNPs. The optical density 
of bacterial strains after 24-h culture in the presence of membranes incorporating metallic NPs is presented in Figure 5.

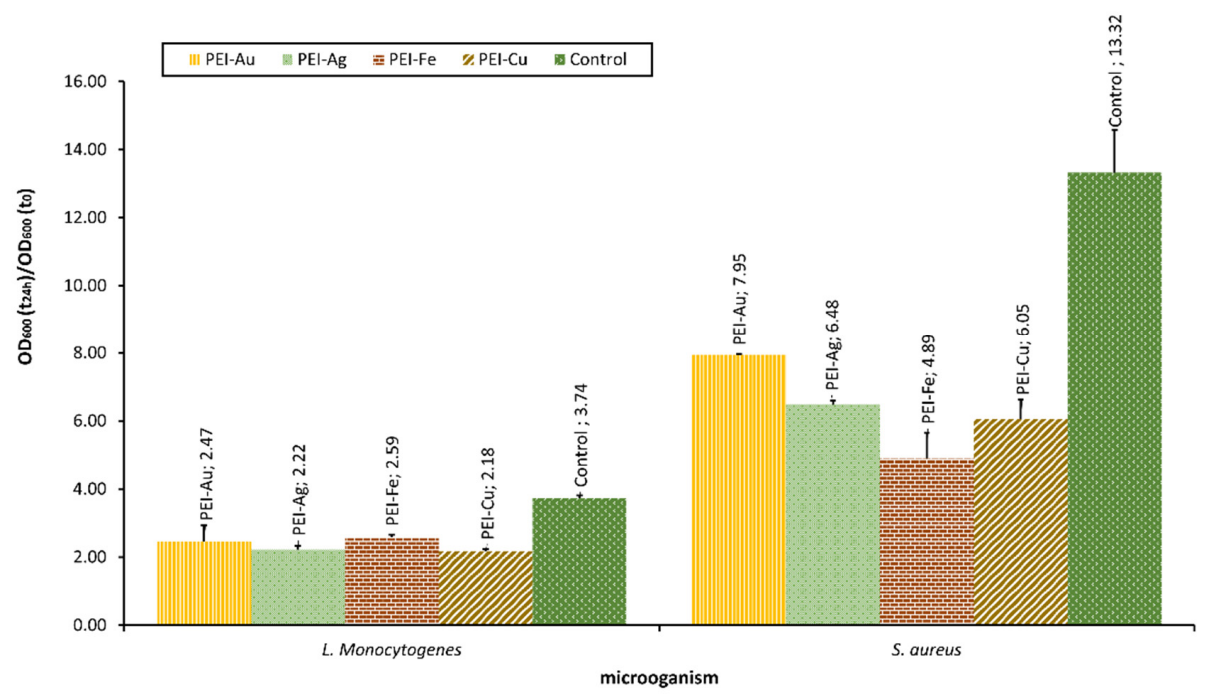

Figure 5. The optical density of bacterial strains L. monocytogenes and S. aureus after 24-h culture in the presence of nanocomposite membrane material based on polyethyleneimine (PEI) with incorporated metallic NPs. Key to the symbols: PEI-Au-polyethylenimine incorporating gold nanoparticles; PEI-Ag_polyethylenimine incorporating silver nanoparticles; PEI-Fe-polyethylenimine incorporating $\mathrm{Fe}_{3} \mathrm{O}_{4}$ nanoparticles; PEI-Cu-polyethylenimine incorporating copper nanoparticles. The values are presented as mean $\pm \mathrm{SD}$.

The applied NPs proved to exert bacteriostatic influence towards both L. monocytogenes and S.aureus strains. Furthermore, there was a statistically significant difference between the OD of L. monocytogenes or S. aureus after $24 \mathrm{~h}$ of culture in the presence of material with incorporated metallic nanoparticles and the control. Material involving CuNPs proved a more substantial bacteriostatic effect on L. monocytogenes than the other membranes. This observation reflects the effect on eukaryotic cells observed by some authors, indicating the more decisive influence of CuNPs compared with other metallic NPs. In the case of $S$. aureus, this pattern was not observed. There was no statistical difference between the membranes involving $\mathrm{CuNPs}$ and $\mathrm{Fe}_{3} \mathrm{O}_{4} \mathrm{NPs}$.

\section{Membranes Involving NPs as the Bacteriostatic Factor for Dressings for Wound Healing of Skin and Bones}

Such elements as metallic nanoparticles, such as $\mathrm{Cu}, \mathrm{Zn}$, and silver (Ag), can prevent infections via their antibacterial activity [214]. For example, wound dressings based on chitosan, such as chitosan/carboxymethyl chitosan/silver nanoparticles (CTS I CMCTS I AgNPs) polyelectrolyte composite based on natural polymers with no chemical reductant involved have been examined for this purpose. The application of CTS I CMCTS I AgNPs hydrogel to wound healing performed using the P. aeruginosa infected wound mice model demonstrated slightly better effects than FAC, the widely used cream in clinics [214]. Some authors explored nanosilver particles-collagen/chitosan hybrid scaffolds' (NAg-CCS) performance in vivo on a rodent model, observing the improved condition of the wound bed and the progress of normal inflammatory stage without unwanted extension or aggravation, which would allow avoiding scar formation. Moreover, the minimal inhibitory concentration of AgNPs in the scaffold, observed on S. aureus and E. coli, was $\leq 10 \mathrm{ppm} \mathrm{[215].} \mathrm{Another}$ membrane fabricated of chitosan/nano- hydroxyapatite/nanosilver composites proved that the material was non-toxic to rat osteoprogenitor cells and human osteosarcoma cell line and exerted broad-spectrum antibacterial activity against Gram-negative and Gram-positive bacteria [216]. The composition of hydroxyapatite coatings with silver NPs was applied to find the balance between the optimal osseointegration and antimicrobial properties of coated 
commercially available TiAl6V4 alloy implants [217]. However, bacterial resistance to silver is low; during over 40 years, E. coli, Enterobacter cloacae, Klebsiella pneumoniae, Acinetobacter baumannii, Salmonella typhimurium, and Pseudomonas stutzeri have been reported as silverresistant strains [218-222]. One of them, A. baumanni, a Gram-negative coccobacillus, was recently listed as the "number one" critical level priority pathogen because of the significant rise of resistance against antibiotics [223].

Our team examined the difference of influence of AuNPs or AgNPs on A. baumanni after $24 \mathrm{~h}$ cultivation in the presence of material with incorporated nanoparticles. No significant difference was found between the AgNPs and the AuNPs containing material using SEM microscopic analysis. Figure 6 presents the SEM visualization of different nanocomposite materials with $A$. baumanni.
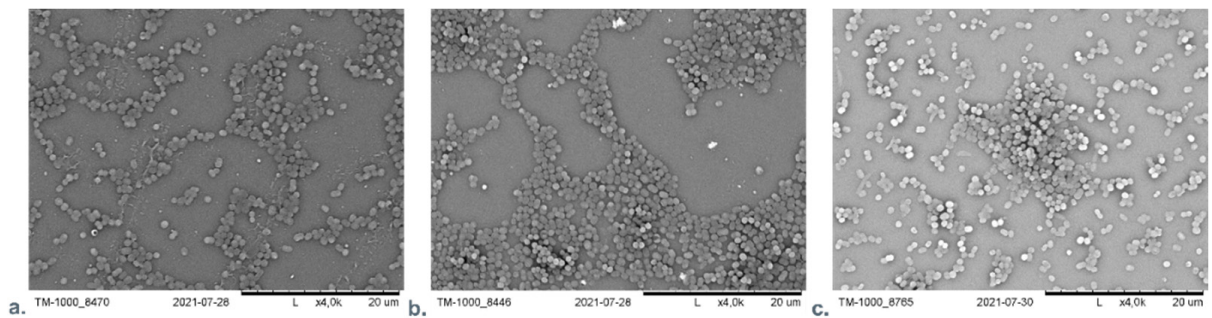

Figure 6. The SEM visualization of nanocomposite material based on polyethyleneimine (PEI) with incorporated AuNPs or AgNPs with A. baumanni after 24-h cultivation. (a): PEI-AuNPs membrane; (b): PEI-AgNPs membrane; (c): Control-A. baumanni after $24 \mathrm{~h}$ of cultivation without membrane.

Our team is currently studying the influence of nanocomposite materials on selected bacterial cells. For example, the interaction with materials involving Au, constructed for bone-skin interface [213], was assessed. The materials proved to be non-toxic towards the human skin cells, and osteoblasts [213] exhibited some bacteriostatic influence. It was observed that the NPs involvement in polyethyleneimine allowed for OD decline compared with the control (bacterial strains cultivated without the membrane film presence) in S. aureus. In the case of L. monocytogenes, OD values did not significantly differ for examined membranes involved, except for $\mathrm{Au}$, some other additives such as HAP and/or FUOL and control. The optical density of bacterial strains after the 24-h culture in the presence of membranes designed for the bone-skin interface is presented in Figure 7.

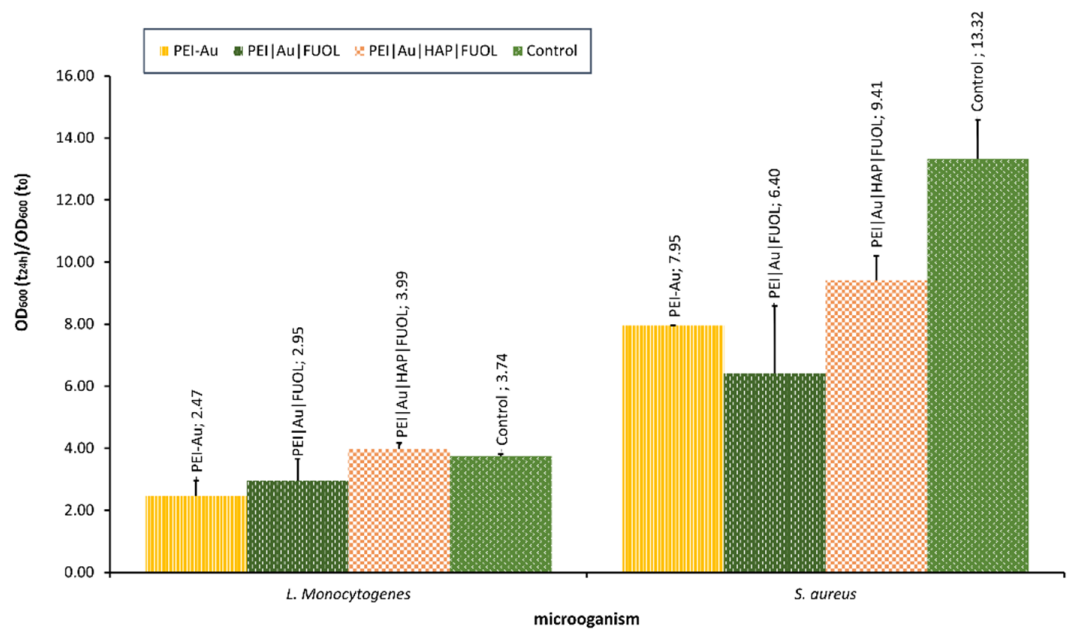

Figure 7. The optical density of bacterial strains L. monocytogenes and S. aureus after 24-h culture in the presence of nanocomposite membrane material based on polyethyleneimine (PEI) with incorporated AuNPs. Key to the symbols: PEI-Au-polyethylenimine incorporating gold nanoparticles; PEI | Au I FUOL-polyethylenimine incorporating gold nanoparticles and fullerenol, PEI$\mathrm{Au}$ I HAP-FUOL-polyethylenimine incorporating gold nanoparticles and hydroxyapatite mixed with fullerenol. The values are presented as mean \pm SD. 


\section{Conclusions}

Nevertheless, there is still no superior substitute for patients' tissues for reconstruction purposes; the field of wound care is constantly being explored in the name of developing new technology and products to facilitate healing. The new product generation consists of nanocomposite materials with antibacterial and anti-inflammatory properties that influence wound healing. Nevertheless, there are concerns regarding their usage in the clinic, such as possible adverse effects on eukaryotic cells. Thus, a balance between bacteriostatic and cytotoxic activity is vital in materials design. Moreover, the problem of bacterial resistance arises due to bacterial adaptation to silver, the mechanism of which is unexplored. Therefore, the design of the material ensuring antibacterial activity against microorganisms, including multidrug resistance, is a constant challenge.

Author Contributions: Conceptualization, A.K. and L.H.G.; methodology, L.H.G., A.K., A.L., A.G., M.D. and R.S.; validation, L.H.G.; formal analysis, L.H.G. and A.K.; investigation, A.K., A.L., A.G., M.D., R.S., A.M. and L.H.G.; writing-original draft preparation, A.K. and L.H.G.; writing-review and editing, L.H.G.; visualization, A.K. and L.H.G.; supervision, L.H.G. All authors have read and agreed to the published version of the manuscript.

Funding: Nalecz Institute of Biocybernetics and Biomedical Engineering Polish Academy of Sciences, Warsaw, Poland.

Institutional Review Board Statement: Not applicable.

Informed Consent Statement: Not applicable.

Conflicts of Interest: The authors declare no conflict of interest.

\section{References}

1. Nussbaum, S.R.; Carter, M.J.; Fife, C.E.; DaVanzo, J.; Haught, R.; Nusgart, M.; Cartwright, D. An Economic Evaluation of the Impact, Cost, and Medicare Policy Implications of Chronic Nonhealing Wounds. Value Health 2018, 21, 27-32. [CrossRef] [PubMed]

2. Guest, J.F.; Ayoub, N.; McIlwraith, T.; Uchegbu, I.; Gerrish, A.; Weidlich, D.; Vowden, K.; Vowden, P. Health economic burden that different wound types impose on the UK's National Health Service. Int. Wound J. 2017, 14, 322-330. [CrossRef] [PubMed]

3. Lindholm, C.; Searle, R. Wound management for the 21st century: Combining effectiveness and efficiency. Int. Wound J. 2016, 13 (Suppl. S2), 5-15. [CrossRef] [PubMed]

4. Mahmoudi, M.; Gould, L.J. Opportunities and Challenges of the Management of Chronic Wounds: A Multidisciplinary Viewpoint. Chronic Wound Care Manag. Res. 2020, 7, 27-36. [CrossRef]

5. Sorg, H.; Tilkorn, D.J.; Hager, S.; Hauser, J.; Mirastschijski, U. Skin Wound Healing: An Update on the Current Knowledge and Concepts. Eur. Surg. Res. 2017, 58, 81-94. [CrossRef] [PubMed]

6. Li, Y.; Wu, J.; Luo, G.; He, W. Functions of V $\gamma 4$ T Cells and Dendritic Epidermal T Cells on Skin Wound Healing. Front. Immunol. 2018, 9, 1099. [CrossRef] [PubMed]

7. Stoica, A.E.; Chircov, C.; Grumezescu, A.M. Nanomaterials for Wound Dressings: An Up-to-Date Overview. Molecules 2020, 25, 2699. [CrossRef]

8. Schultz, G.S.; Chin, G.A.; Moldawer, L.; Diegelmann, R.F. Principles of Wound Healing. Diabet. Foot Probl. $2011,395-402$.

9. Li, B.; Wang, J.H.-C. Fibroblasts and Myofibroblasts in Wound Healing: Force Generation and Measurement. J. Tissue Viability 2011, 20, 108. [CrossRef]

10. Varkey, M.; Jie, D.; Tredget, E. The potential role of stem cells in wound healing. Wounds UK 2013, 9, 60-66.

11. Mihai, M.M.; Dima, M.B.; Dima, B.; Holban, A.M. Nanomaterials for Wound Healing and Infection Control. Materials 2019, 12, 2176. [CrossRef] [PubMed]

12. Guo, S.; DiPietro, L.A. Factors Affecting Wound Healing. J. Dent. Res. 2010, 89, 219. [CrossRef] [PubMed]

13. Wilkinson, H.N.; Hardman, M.J. Wound healing: Cellular mechanisms and pathological outcomes. Open Biol. 2020, 10, 200223. [CrossRef] [PubMed]

14. DiPietro, L.A.; Burdick, M.; Low, Q.E.; Kunkel, S.L.; Strieter, R.M. Mip-1 $\alpha$ as a critical macrophage chemoattractant in murine wound repair. J. Clin. Invest. 1998, 101, 1693-1698. [CrossRef] [PubMed]

15. DiPietro, L.A.; Reintjes, M.G.; Low, Q.E.H.; Levi, B.; Gamelli, R.L. Modulation of macrophage recruitment into wounds by monocyte chemoattractant protein-1. Wound Repair Regen. 2001, 9, 28-33. [CrossRef] [PubMed]

16. Greenlee-Wacker, M.C. Clearance of apoptotic neutrophils and resolution of inflammation. Immunol. Rev. 2016, 273, 357-370. [CrossRef]

17. Pongkitwitoon, S.; Weinheimer-Haus, E.M.; Koh, T.J.; Judex, S. Low-intensity vibrations accelerate proliferation and alter macrophage phenotype in vitro. J. Biomech. 2016, 49, 793-796. [CrossRef] [PubMed] 
18. Khanna, S.; Biswas, S.; Shang, Y.; Collard, E.; Azad, A.; Kauh, C.; Bhasker, V.; Gordillo, G.M.; Sen, C.K.; Roy, S. Macrophage dysfunction impairs resolution of inflammation in the wounds of diabetic mice. PLOS ONE 2010, 5. [CrossRef]

19. DiPietro, L.A.; Wilgus, T.A.; Koh, T.J. Macrophages in Healing Wounds: Paradoxes and Paradigms. Int. J. Mol. Sci. 2021, 22, 950. [CrossRef]

20. Wang, X.; Balaji, S.; Steen, E.H.; Rae, M.M.; Blum, A.J.; Miao, Q.; Butte, M.J.; Bollyky, P.L.; Keswani, S.G. T Lymphocytes Attenuate Dermal Scarring by Regulating Inflammation, Neovascularization, and Extracellular Matrix Remodeling. Adv. Wound Care 2019, 8, 527-537. [CrossRef]

21. Nosbaum, A.; Prevel, N.; Truong, H.-A.; Mehta, P.; Ettinger, M.; Scharschmidt, T.C.; Ali, N.H.; Pauli, M.L.; Abbas, A.K.; Rosenblum, M.D. Cutting Edge: Regulatory T Cells Facilitate Cutaneous Wound Healing. J. Immunol. 2016, 196, 2010-2014. [CrossRef] [PubMed]

22. Velnar, T.; Gradisnik, L. Tissue Augmentation in Wound Healing: The Role of Endothelial and Epithelial Cells. Med. Arch. 2018, 72, 444. [CrossRef] [PubMed]

23. Lawrence, W.T. Physiology of the acute wound. Clin. Plast. Surg. 1998, 25, 321-340. [CrossRef]

24. Campos, A.C.L.; Groth, A.K.; Branco, A.B. Assessment and nutritional aspects of wound healing. Curr. Opin. Clin. Nutr. Metab. Care 2008, 11, 281-288. [CrossRef]

25. Ayavoo, T.; Murugesan, K.; Gnanasekaran, A. Roles and mechanisms of stem cell in wound healing. Stem Cell Investig. 2021, 8, 4 [CrossRef]

26. Cha, J.; Falanga, V. Stem cells in cutaneous wound healing. Clin. Dermatol. 2007, 25, 73-78. [CrossRef]

27. Rea, S.; Giles, N.L.; Webb, S.; Adcroft, K.F.; Evill, L.M.; Strickland, D.H.; Wood, F.M.; Fear, M.W. Bone marrow-derived cells in the healing burn wound-More than just inflammation. Burns 2009, 35, 356-364. [CrossRef]

28. Mustoe, T. Understanding chronic wounds: A unifying hypothesis on their pathogenesis and implications for therapy. Am. J. Surg. 2004, 187, S65-S70. [CrossRef]

29. DiPietro, L.A.; Burns, A.L.; Sisco, M.; Mustoe, T.A. Animal Models of Ischemic Wound Healing: Toward an Approximation of Human Chronic Cutaneous Ulcers in Rabbit and Rat. In Wound Healing; Humana Press: New York, NY, USA, 2003; Volume 78, pp. 055-065.

30. Mustoe, T.A.; O'Shaughnessy, K.; Kloeters, O. Chronic wound pathogenesis and current treatment strategies: A unifying hypothesis. Plast. Reconstr. Surg. 2006, 117, 35S-41S. [CrossRef]

31. Tandara, A.A.; Mustoe, T.A. Oxygen in Wound Healing-More than a Nutrient. World J. Surg. 2004, 28, 294-300. [CrossRef]

32. Beyene, R.T.; Derryberry, S.L.; Barbul, A. The Effect of Comorbidities on Wound Healing. Surg. Clin. 2020, 100, 695-705. [CrossRef] [PubMed]

33. Rodriguez, P.G.; Felix, F.N.; Woodley, D.T.; Shim, E.K. The Role of Oxygen in Wound Healing: A Review of the Literature Dermatol. Surg. 2008, 34, 1159-1169. [CrossRef]

34. Anaya, D.A.; Dellinger, E.P. The Obese Surgical Patient: A Susceptible Host for Infection. Surg. Infect. 2006, 7, 473-480. [CrossRef] [PubMed]

35. Wilson, J.A.; Clark, J.J. Obesity: Impediment to postsurgical wound healing. Adv. Skin Wound Care 2004, 17, 426-435. [CrossRef] [PubMed]

36. Arnold, M.; Barbul, A. Nutrition and wound healing. Plast. Reconstr. Surg. 2006, 117, 42S-58S. [CrossRef] [PubMed]

37. Tong, B.; Barbul, A. Cellular and Physiological Effects of Arginine. Mini-Rev. Med. Chem. 2012, 4, 823-832. [CrossRef]

38. Da Costa, M.; Campos, A.; Coelho, J.; de Barros, A.; Matsumoto, H. Oral glutamine and the healing of colonic anastomoses in rats. J. Parenter. Enter. Nutr. 2003, 27, 182-185. [CrossRef]

39. Heyman, H.; Van De Looverbosch, D.E.; Meijer, E.P.; Schols, J.M. Benefits of an oral nutritional supplement on pressure ulcer healing in long-term care. J. Wound Care 2013, 17, 476-480. [CrossRef]

40. Godbout, J.P.; Glaser, R. Stress-Induced Immune Dysregulation: Implications for Wound Healing, Infectious Disease and Cancer. J. Neuroimmune Pharmacol. 2006, 1, 421-427. [CrossRef]

41. Gouin, J.P.; Kiecolt-Glaser, J.K. The Impact of Psychological Stress on Wound Healing: Methods and Mechanisms. Immunol. Allergy Clin. 2011, 31, 81. [CrossRef]

42. Wynn, M.; Holloway, S. The impact of psychological stress on wound healing a theoretical and clinical perspective - review. Wounds UK 2019, 15, 20-27.

43. Bonifant, H.; Holloway, S. A review of the effects of ageing on skin integrity and wound healing. Br. J. Community Nurs. 2019, 24, S28-S33. [CrossRef] [PubMed]

44. Keylock, K.T.; Vieira, V.J.; Wallig, M.A.; DiPietro, L.A.; Schrementi, M.; Woods, J.A. Exercise accelerates cutaneous wound healing and decreases wound inflammation in aged mice. Am. J. Physiol. Regul. Integr. Comp. Physiol. 2008, 294, 179-184. [CrossRef] [PubMed]

45. Venosi, S.; Ceccarelli, G.; De Angelis, M.; Laghi, L.; Bianchi, L.; Martinelli, O.; Maruca, D.; Cavallari, E.N.; Toscanella, F.; Vassalini, P.; et al. Infected chronic ischemic wound topically treated with a multi-strain probiotic formulation: A novel tailored treatment strategy. J. Transl. Med. 2019, 17, 364. [CrossRef]

46. Kalan, L.; Meisel, J.; Loesche, M.; Horwinski, J.; Soaita, I.; Chen, X.; Grice, E. Strain-and species-level variation in the microbiome of diabetic wounds is associated with clinical outcomes and therapeutic efficacy. Cell Host Microbe 2019, 25, 641-655. [CrossRef] 
47. Lai, Y.; Nardo, A.D.; Nakatsuji, T.; Leichtle, A.; Yang, Y.; Cogen, A.; Gallo, R. Commensal bacteria regulate Toll-like receptor 3-dependent inflammation after skin injury. Nat. Med. 2009, 15, 1377. [CrossRef]

48. Harrison, O.; Linehan, J.; Shih, H.; Bouladoux, N.; Han, S.; Smelkinson, M.; Belkaid, Y. Commensal-specific T cell plasticity promotes rapid tissue adaptation to injury. Science 2019, 363, eaat6280. [CrossRef]

49. Ovington, L. Bacterial toxins and wound healing. Ostomy/Wound Manag. 2003, 49, 8-12.

50. Sood, A.; Granick, M.S.; Tomaselli, N.L. Wound Dressings and Comparative Effectiveness Data. Adv. Wound Care 2014, 3, 511-529. [CrossRef]

51. Tomic-Canic, M.; Burgess, J.L.; O’Neill, K.E.; Strbo, N.; Pastar, I. Skin Microbiota and its Interplay with Wound Healing. Am. J. Clin. Dermatol. 2020, 21, 36-43. [CrossRef]

52. Misic, A.M.; Gardner, S.E.; Grice, E.A. The Wound Microbiome: Modern Approaches to Examining the Role of Microorganisms in Impaired Chronic Wound Healing. Adv. Wound Care 2014, 3, 502-510. [CrossRef] [PubMed]

53. Gupta, S.; Andersen, C.; Black, J.; de Leon, J.; Fife, C.; Lantis, J.C.; Niezgoda, J.; Snyder, R.; Sumpio, B.; Tettelbach, W.; et al Management of Chronic Wounds: Diagnosis, Preparation, Treatment, and Follow-up. Wounds a Compend. Clin. Res. Pract. 2017, 29, S19-S36.

54. Broussard, K.C.; Powers, J.G. Wound dressings: Selecting the most appropriate type. Am. J. Clin. Dermatol. 2013, 14, 449-459. [CrossRef] [PubMed]

55. Fleck, C.A. Wound assessment parameters and dressing selection. Adv. Skin Wound Care 2006, 19, 364-373. [CrossRef] [PubMed]

56. Dealey, C. The Care of Wounds: A Guide for Nurses; Wiley-Blackwell: Hoboken, NJ, USA, 2012.

57. Shi, C.; Wang, C.; Liu, H.; Li, Q.; Li, R.; Zhang, Y.; Liu, Y.; Shao, Y.; Wang, J. Selection of Appropriate Wound Dressing for Various Wounds. Front. Bioeng. Biotechnol. 2020, 8, 182. [CrossRef] [PubMed]

58. Biotec Betaglucans Wound Assessment-Why Continuity and Documentation Is So Important. Available online: https://woulgan com/wound-assessment/ (accessed on 23 January 2022).

59. Rezvani Ghomi, E.; Khalili, S.; Nouri Khorasani, S.; Esmaeely Neisiany, R.; Ramakrishna, S. Wound dressings: Current advances and future directions. J. Appl. Polym. Sci. 2019, 136, 47738. [CrossRef]

60. Xu, R.; Xia, H.; He, W.; Li, Z.; Zhao, J.; Liu, B.; Wang, Y.; Lei, Q.; Kong, Y.; Bai, Y.; et al. Controlled water vapor transmission rate promotes wound-healing via wound re-epithelialization and contraction enhancement. Sci. Rep. 2016, 6, 24596. [CrossRef] [PubMed]

61. Ousey, K.; Cutting, K.F.; Rogers, A.A.; Rippon, M.G. The importance of hydration in wound healing: Reinvigorating the clinical perspective. J. Wound Care 2016, 25, 122-130. [CrossRef]

62. Sirvio, L.M.; Grussing, D.M. The effect of gas permeability of film dressings on wound environment and healing. J. Invest. Dermatol. 1989, 93, 528-531. [CrossRef]

63. Dumville, J.C.; Gray, T.A.; Walter, C.J.; Sharp, C.A.; Page, T.; Macefield, R.; Blencowe, N.; Milne, T.K.G.; Reeves, B.C.; Blazeby, J Dressings for the prevention of surgical site infection. Cochrane Database Syst. Rev. 2016, 2016, CD003091. [CrossRef]

64. Philippe, A. [Secondary dressings]. Soins 2016, 61, 51-53. [CrossRef] [PubMed]

65. Weller, C.; Sussman, G. Wound Dressings Update. J. Pharm. Pract. Res. 2006, 36, 318-324. [CrossRef]

66. White, R.; Cutting, K. Maceration of the skin and wound bed by indication. In Trends in Wound Care III.; White, R., Ed.; Quay Books: London, UK, 2004; pp. 23-39.

67. Georgescu, M.; C Chifiriuc, M.; Marutescu, L.; Gheorghe, I.; Lazar, V.; Bolocan, A.; Bertesteanu, S. Bioactive Wound Dressings for the Management of Chronic Wounds. Curr. Org. Chem. 2017, 21, 53-63. [CrossRef]

68. Walker, M.; Hobot, J.A.; Newman, G.R.; Bowler, P.G. Scanning electron microscopic examination of bacterial immobilisation in a carboxymethyl cellulose (AQUACEL®) and alginate dressings. Biomaterials 2003, 24, 883-890. [CrossRef]

69. Dumville, J.C.; O’Meara, S.; Deshpande, S.; Speak, K. Alginate dressings for healing diabetic foot ulcers. Cochrane Database Syst. Rev. 2012. [CrossRef]

70. Dumville, J.C.; Keogh, S.J.; Liu, Z.; Stubbs, N.; Walker, R.M.; Fortnam, M. Alginate dressings for treating pressure ulcers. Cochrane Database Syst. Rev. 2015, 2015, CD009110. [CrossRef]

71. Francesko, A.; Petkova, P.; Tzanov, T. Hydrogel Dressings for Advanced Wound Management. Curr. Med. Chem. 2019, 25, 5782-5797. [CrossRef]

72. Kamoun, E.A.; Kenawy, E.R.S.; Chen, X. A review on polymeric hydrogel membranes for wound dressing applications: PVA-based hydrogel dressings. J. Adv. Res. 2017, 8, 217-233. [CrossRef]

73. Thomas, S.; Hay, P. Fluid handling properties of hydrogel dressings. Ostomy/Wound. Manag. 1995, 41, 54-56.

74. Wang, H.; Xu, Z.; Zhao, M.; Liu, G.; Wu, J. Advances of hydrogel dressings in diabetic wounds. Biomater. Sci. 2021, 9, 1530-1546. [CrossRef]

75. Kong, D.; Zhang, Q.; You, J.; Cheng, Y.; Hong, C.; Chen, Z.; Jiang, T.; Hao, T. Adhesion loss mechanism based on carboxymethyl cellulose-filled hydrocolloid dressings in physiological wounds environment. Carbohydr. Polym. 2020, 235, 115953. [CrossRef] [PubMed]

76. Dutra, R.A.A.; Salomé, G.M.; Alves, J.R.; Pereira, V.O.S.; Miranda, F.D.; Vallim, V.B.; De Brito, M.J.A.; Ferreira, L.M. Using transparent polyurethane film and hydrocolloid dressings to prevent pressure ulcers. J. Wound Care 2015, 24, 268-275. [CrossRef] [PubMed] 
77. Thomas, S. Hydrocolloid dressings in the management of acute wounds: A review of the literature. Int. Wound J. 2008, 5, 602-613. [CrossRef] [PubMed]

78. Jung, J.A.; Han, S.K.; Jeong, S.H.; Dhong, E.S.; Park, K.G.; Kim, W.K. In vitro evaluation of betafoam, a new polyurethane foam dressing. Adv. Ski. Wound Care 2017, 30, 262-270. [CrossRef] [PubMed]

79. Yoshimura, M.; Ohura, N.; Tanaka, J.; Ichimura, S.; Kasuya, Y.; Hotta, O.; Kagaya, Y.; Sekiyama, T.; Tannba, M.; Suzuki, N. Soft silicone foam dressing is more effective than polyurethane film dressing for preventing intraoperatively acquired pressure ulcers in spinal surgery patients: The Border Operating room Spinal Surgery (BOSS) trial in Japan. Int. Wound J. 2018, 15, 188-197. [CrossRef]

80. Yoo, S.C.; Han, S.K.; Shin, Y.W.; Ko, H.W.; Choi, Y.J.; Chung, D.S.; Lee, B., II; Kim, W.K. Comparison of effect of polyurethane foam dressings on epithelialization of white rat. J Korean Soc Plast Reconstr Surg 2003, 30, 231-236.

81. De Queiroz, A.A.A.; Ferraz, H.G.; Abraham, G.A.; Del Mar Fernández, M.; Bravo, A.L.; San Román, J. Development of new hydroactive dressings based on chitosan membranes: Characterization and in vivo behavior. J. Biomed. Mater. Res. Part A 2003, 64A, 147-154. [CrossRef]

82. Achterberg, V.; Meyer-Ingold, W. Hydroactive dressings and serum proteins: An in vitro study. J. Wound Care 2016, 5, 79-82. [CrossRef]

83. Robinson, B.J. The use of a hydrofibre dressing in wound management. J. Wound Care 2013, 9, 32-34. [CrossRef]

84. Pinese, C.; Jebors, S.; Stoebner, P.E.; Humblot, V.; Verdié, P.; Causse, L.; Garric, X.; Taillades, H.; Martinez, J.; Mehdi, A.; et al. Bioactive peptides grafted silicone dressings: A simple and specific method. Mater. Today Chem. 2017, 4, 73-83. [CrossRef]

85. Platt, A.J.; Phipps, A.; Judkins, K. A comparative study of silicone net dressing and paraffin gauze dressing in skin-grafted sites. Burns 1996, 22, 543-545. [CrossRef]

86. Gethin, G.T.; Cowman, S.; Conroy, R.M. The impact of Manuka honey dressings on the surface pH of chronic wounds. Int. Wound J. 2008, 5, 185-194. [CrossRef] [PubMed]

87. Jull, A.; Walker, N.; Parag, V.; Molan, P.; Rodgers, A. Randomized clinical trial of honey-impregnated dressings for venous leg ulcers. Br. J. Surg. 2008, 95, 175-182. [CrossRef] [PubMed]

88. Sharp, A. Beneficial effects of honey dressings in wound management. Nurs. Stand. 2009, 24, 66-74. [CrossRef] [PubMed]

89. Russell, L.; Deeth, M.; Jones, H.M.; Reynolds, T. VACUTE" capillary action dressing: A multicentre, randomized trial. Br. J. Nurs. 2001, 10, S66-S70. [CrossRef]

90. Fraccalvieri, M.; Ruka, E.; Morozzo, U.; Scalise, A.; Salomone, M. The Combination of a Hypertonic Saline Dressing and Negative Pressure Wound Therapy for Quick and Bloodless Debridement of Difficult Lesions in Complicated Patients. Negat. Press. Wound Ther. J. 2015, 2, 5. [CrossRef]

91. Elliott, C. The effects of silver dressings on hronic and burns wound healing. Br. J. Nurs. 2010, 19, S32-S36. [CrossRef]

92. Vlachou, E.; Chipp, E.; Shale, E.; Wilson, Y.T.; Papini, R.; Moiemen, N.S. The safety of nanocrystalline silver dressings on burns: A study of systemic silver absorption. Burns 2007, 33, 979-985. [CrossRef]

93. Aziz, Z.; Abu, S.F.; Chong, N.J. A systematic review of silver-containing dressings and topical silver agents (used with dressings) for burn wounds. Burns 2012, 38, 307-318. [CrossRef]

94. Mooney, E.K.; Lippitt, C.; Friedman, J. Silver dressings. Plast. Reconstr. Surg. 2006, 117, 666-669. [CrossRef]

95. Fitzgerald, D.J.; Renick, P.J.; Forrest, E.C.; Tetens, S.P.; Earnest, D.N.; McMillan, J.; Kiedaisch, B.M.; Shi, L.; Roche, E.D. Cadexomer iodine provides superior efficacy against bacterial wound biofilms in vitro and in vivo. Wound Repair Regen. 2017, $25,13-24$. [CrossRef] [PubMed]

96. Mertz, P.M.; Oliveira-Gandia, M.F.; Davis, S.C. The Evaluation of a Cadexomer Iodine Wound Dressing on Methicillin Resistant Staphylococcus Aureus (MRSA) in Acute Wounds. Dermatol. Surg. 1999, 25, 89-93. [CrossRef] [PubMed]

97. Lansdown, A.B.G.; Mirastschijski, U.; Stubbs, N.; Scanlon, E.; Ågren, M.S. Zinc in wound healing: Theoretical, experimental, and clinical aspects. Wound Repair Regen. 2007, 15, 2-16. [CrossRef] [PubMed]

98. Williams, C. Examining the range of medicated and paste-impregnated bandages. Br. J. Nurs. 2013, 8, 1019-1020. [CrossRef]

99. Mosti, G.; Crespi, A.; Mattaliano, V. Comparison Between a New, Two-component Compression System With Zinc Paste Bandages for Leg Ulcer Healing: A Prospective, Multicenter, Randomized, Controlled Trial Monitoring Sub-bandage Pressures. Wounds Compend. Clin. Res. Pract. 2011, 23, 126-134.

100. Broughton, G.; Janis, J.E.; Attinger, C.E. A brief history of wound care. Plast. Reconstr. Surg. 2006, 117, 6S-11S. [CrossRef]

101. Clark, R.A.F.; Ghosh, K.; Tonnesen, M.G. Tissue Engineering for Cutaneous Wounds. J. Invest. Dermatol. 2007, 127, 1018-1029. [CrossRef]

102. Yildirimer, L.; Hobson, D.; Yuan, Z.; Lin, W.; Cui, W.; Zhao, X. Tissue-engineered human skin equivalents and their applications in wound healing. In Tissue Engineering for Artificial Organs: Regenerative Medicine, Smart Diagnostics and Personalized Medicine; Wiley-VCH: Weinheim, Germany, 2017; pp. 215-241.

103. Halim, A.S.; Khoo, L.; Jumaat, S.; Yussof, M. Biologic and synthetic skin substitutes: An overview. Indian J. Plast. Surg. 2020, 43, S23-S28. [CrossRef]

104. Shukla, A.K.; Dey, N.; Nandi, P.; Ranjan, M. Acellular Dermis as a Dermal Matrix of Tissue Engineered Skin Substitute for Burns Treatment. Ann Public Heal. Res 2015, 2, 1023.

105. Mir, M.; Ali, M.N.; Barakullah, A.; Gulzar, A.; Arshad, M.; Fatima, S.; Asad, M. Synthetic polymeric biomaterials for wound healing: A review. Prog. Biomater. 2018, 7, 1-21. [CrossRef] 
106. Augustine, R.; Kalarikkal, N.; Thomas, S. Advancement of wound care from grafts to bioengineered smart skin substitutes. Prog Biomater 2014, 3, 103-113. [CrossRef] [PubMed]

107. Moeini, A.; Pedram, P.; Makvandi, P.; Malinconico, M.; Gomez d'Ayala, G. Wound healing and antimicrobial effect of active secondary metabolites in chitosan-based wound dressings: A review. Carbohydr. Polym. 2020, 233, 115839. [CrossRef] [PubMed]

108. Graça, M.F.P.; Miguel, S.P.; Cabral, C.S.D.; Correia, I.J. Hyaluronic acid-Based wound dressings: A review. Carbohydr. Polym. 2020, 241, 116364. [CrossRef] [PubMed]

109. Mi, X.; Xu, H.; Yang, Y. Submicron amino acid particles reinforced $100 \%$ keratin biomedical films with enhanced wet properties via interfacial strengthening. Colloids Surf. B Biointerfaces 2019, 177, 33-40. [CrossRef]

110. Costa, N.N.; de Faria Lopes, L.; Ferreira, D.F.; de Prado, E.M.L.; Severi, J.A.; Resende, J.A.; de Paula Careta, F.; Ferreira, M.C.P.; Carreira, L.G.; de Souza, S.O.L.; et al. Polymeric films containing pomegranate peel extract based on PVA/starch/PAA blends for use as wound dressing: In vitro analysis and physicochemical evaluation. Mater. Sci. Eng. C 2020, 109, 110643. [CrossRef]

111. Arthe, R.; Arivuoli, D.; Ravi, V. Preparation and characterization of bioactive silk fibroin/paramylon blend films for chronic wound healing. Int. J. Biol. Macromol. 2020, 154, 1324-1331. [CrossRef]

112. Joshi, A.; Xu, Z.; Ikegami, Y.; Yoshida, K.; Sakai, Y.; Joshi, A.; Kaur, T.; Nakao, Y.; Yamashita, Y.; Baba, H.; et al. Exploiting synergistic effect of externally loaded bFGF and endogenous growth factors for accelerated wound healing using heparin functionalized PCL/gelatin co-spun nanofibrous patches. Chem. Eng. J. 2021, 404, 126518. [CrossRef]

113. Aksoy, E.A.; Sezer, U.A.; Kara, F.; Hasirci, N. Heparin/Chitosan/Alginate Complex Scaffolds as Wound Dressings: Characterization and Antibacterial Study Against Staphylococcus epidermidis. J. Biomater. Tissue Eng. 2015, 5, 104-113. [CrossRef]

114. Fleck, C.A.; Simman, R. Modern Collagen Wound Dressings: Function and Purpose. J. Am. Col. Certif. Wound Spec. 2010, $2,50-54$. [CrossRef]

115. Chao, S.; Li, Y.; Zhao, R.; Zhang, L.; Li, Y.; Wang, C.; Li, X. Synthesis and characterization of tigecycline-loaded sericin/poly(vinyl alcohol) composite fibers via electrospinning as antibacterial wound dressings. J. Drug Deliv. Sci. Technol. 2018, 44, 440-447. [CrossRef]

116. Abbasi, A.R.; Sohail, M.; Minhas, M.U.; Khaliq, T.; Kousar, M.; Khan, S.; Hussain, Z.; Munir, A. Bioinspired sodium alginate based thermosensitive hydrogel membranes for accelerated wound healing. Int. J. Biol. Macromol. 2020, 155, 751-765. [CrossRef] [PubMed]

117. Wang, T.; Wang, J.; Wang, R.; Yuan, P.; Fan, Z.; Yang, S. Preparation and properties of ZnO/sodium alginate bi-layered hydrogel films as novel wound dressings. New J. Chem. 2019, 43, 8684-8693. [CrossRef]

118. Kimna, C.; Tamburaci, S.; Tihminlioglu, F. Novel zein-based multilayer wound dressing membranes with controlled release of gentamicin. J. Biomed. Mater. Res. Part B Appl. Biomater. 2019, 107, 2057-2070. [CrossRef] [PubMed]

119. Wang, Y.; Xie, R.; Li, Q.; Dai, F.; Lan, G.; Shang, S.; Lu, F. A self-adapting hydrogel based on chitosan/oxidized konjac glucomannan/AgNPs for repairing irregular wounds. Biomater. Sci. 2020, 8, 1910-1922. [CrossRef]

120. Gomes Neto, R.J.; Genevro, G.M.; Paulo, L.d.A.; Lopes, P.S.; de Moraes, M.A.; Beppu, M.M. Characterization and in vitro evaluation of chitosan/konjac glucomannan bilayer film as a wound dressing. Carbohydr. Polym. 2019, 212, 59-66. [CrossRef]

121. Chen, H.; Lan, G.; Ran, L.; Xiao, Y.; Yu, K.; Lu, B.; Dai, F.; Wu, D.; Lu, F. A novel wound dressing based on a Konjac glucomannan/silver nanoparticle composite sponge effectively kills bacteria and accelerates wound healing. Carbohydr. Polym. 2018, 183, 70-80. [CrossRef]

122. Mogoşanu, G.; Grumezescu, A. Natural and synthetic polymers for wounds and burns dressing. Int. J. Pharm. 2014, 463, 127-136. [CrossRef]

123. Uzun, M. A review of wound management materials. J. Text. Eng. Fash. Technol. 2018, Volume 4, 53-59. [CrossRef]

124. Munim, S.A.; Raza, Z.A. Poly(lactic acid) based hydrogels: Formation, characteristics and biomedical applications. J. Porous Mater. 2018, 26, 881-901. [CrossRef]

125. Mazloom-Jalali, A.; Shariatinia, Z.; Tamai, I.A.; Pakzad, S.R.; Malakootikhah, J. Fabrication of chitosan-polyethylene glycol nanocomposite films containing ZIF-8 nanoparticles for application as wound dressing materials. Int. J. Biol. Macromol. 2020, 153, 421-432. [CrossRef]

126. Hassan, A.A.; Radwan, H.A.; Abdelaal, S.A.; Al-Radadi, N.S.; Ahmed, M.K.; Shoueir, K.R.; Hady, M.A. Polycaprolactone based electrospun matrices loaded with Ag/hydroxyapatite as wound dressings: Morphology, cell adhesion, and antibacterial activity. Int. J. Pharm. 2021, 593, 120143. [CrossRef] [PubMed]

127. Contardi, M.; Kossyvaki, D.; Picone, P.; Summa, M.; Guo, X.; Heredia-Guerrero, J.A.; Giacomazza, D.; Carzino, R.; Goldoni, L.; Scoponi, G.; et al. Electrospun polyvinylpyrrolidone (PVP) hydrogels containing hydroxycinnamic acid derivatives as potential wound dressings. Chem. Eng. J. 2021, 409, 128144. [CrossRef]

128. Savencu, I.; Iurian, S.; Porfire, A.; Bogdan, C.; Tomuță, I. Review of advances in polymeric wound dressing films. React. Funct. Polym. 2021, 168, 105059. [CrossRef]

129. Mathew-Steiner, S.S.; Roy, S.; Sen, C.K. Collagen in Wound Healing. Bioengineering 2021, 8, 63. [CrossRef]

130. Landén, N.X.; Li, D.; Ståhle, M. Transition from inflammation to proliferation: A critical step during wound healing. Cell. Mol. Life Sci. 2016, 73, 3861-3885. [CrossRef]

131. Chaudhry, R.; Chaudhry, S.M.; Babiker, H.M. Physiology, Coagulation Pathways. In StatPearls [Internet]; StatPeartls Publising: Treasure Island, FL, USA, 2018. 
132. Rosique, R.G.; Rosique, M.J.; Farina Junior, J.A. Curbing inflammation in skin wound healing: A review. Int. J. Inflam. 2015, 2015, 316235. [CrossRef]

133. Collagen Dressings Market: Exceptional Biological Properties of Collagen Dressings to Fuel Market Growth I BioSpace. Available online: https:/ / www.biospace.com/article/collagen-dressings-market-exceptional-biological-properties-of-collagen-dressingsto-fuel-market-growth/ (accessed on 4 November 2021).

134. Wound Dressings Market-Global Forecast to 2025 । MarketsandMarkets. Available online: https://www.marketsandmarkets. com/Market-Reports/wound-dressings-market-123903496.html (accessed on 4 November 2021).

135. Masry, M.S.E.; Chaffee, S.; Ghatak, P.D.; Mathew-Steiner, S.S.; Das, A.; Higuita-Castro, N.; Roy, S.; Anani, R.A.; Sen, C.K. Stabilized collagen matrix dressing improves wound macrophage function and epithelialization. FASEB J. 2019, 33, 2144-2155. [CrossRef]

136. Das, A.; Abas, M.; Biswas, N.; Banerjee, P.; Ghosh, N.; Rawat, A.; Khanna, S.; Roy, S.; Sen, C.K. A Modified Collagen Dressing Induces Transition of Inflammatory to Reparative Phenotype of Wound Macrophages. Sci. Rep. 2019, 9, 14293. [CrossRef]

137. Das, A.; Datta, S.; Roche, E.; Chaffee, S.; Jose, E.; Shi, L.; Grover, K.; Khanna, S.; Sen, C.K.; Roy, S. Novel mechanisms of Collagenase Santyl Ointment (CSO) in wound macrophage polarization and resolution of wound inflammation. Sci. Rep. 2018, 8, 1696. [CrossRef]

138. Amirrah, I.N.; Wee, M.F.M.R.; Tabata, Y.; Idrus, R.B.H.; Nordin, A.; Fauzi, M.B. Antibacterial-Integrated Collagen Wound Dressing for Diabetes-Related Foot Ulcers: An Evidence-Based Review of Clinical Studies. Polymers 2020, 12, 2168. [CrossRef]

139. Kallis, P.J.; Friedman, A.J. Collagen Powder in Wound Healing. J. Drugs Dermatol. 2018, 17, 403-408.

140. Chen, S.; Wang, H.; Jian, Z.; Fei, G.; Qian, W.; Luo, G.; Wang, Z.; Xia, H. Novel Poly(vinyl alcohol)/Chitosan/Modified Graphene Oxide Biocomposite for Wound Dressing Application. Macromol. Biosci. 2020, 20, 1900385. [CrossRef] [PubMed]

141. Jayaramudu, T.; Varaprasad, K.; Pyarasani, R.D.; Reddy, K.K.; Kumar, K.D.; Akbari-Fakhrabadi, A.; Mangalaraja, R.V.; Amalraj, J Chitosan capped copper oxide/copper nanoparticles encapsulated microbial resistant nanocomposite films. Int. J. Biol. Macromol. 2019, 128, 499-508. [CrossRef] [PubMed]

142. Hafezi, F.; Scoutaris, N.; Douroumis, D.; Boateng, J. 3D printed chitosan dressing crosslinked with genipin for potential healing of chronic wounds. Int. J. Pharm. 2019, 560, 406-415. [CrossRef] [PubMed]

143. Alven, S.; Aderibigbe, B.A. Hyaluronic Acid-Based Scaffolds as Potential Bioactive Wound Dressings. Polymers 2021, 13, 2102. [CrossRef]

144. Cortes, H.; Caballero-Florán, I.H.; Mendoza-Muñoz, N.; Córdova-Villanueva, E.N.; Escutia-Guadarrama, L.; FigueroaGonzález, G.; Reyes-Hernández, O.D.; González-Del Carmen, M.; Varela-Cardoso, M.; Magaña, J.; et al. Hyaluronic acid in wound dressings. Cell. Mol. Biol. 2020, 66, 191-198. [CrossRef]

145. Khan, A.; Xu, M.; Wang, T.; You, C.; Wang, X.; Ren, H.; Zhou, H.; Khan, A.; Han, C.; Li, P. Catechol cross-linked antimicrobial peptide hydrogels prevent multidrug-resistant Acinetobacter baumannii infection in burn wounds. Biosci. Rep. 2019, 39, BSR20190504. [CrossRef]

146. Yue, X.; Liu, L.; Wu, Y.; Liu, X.; Li, S.; Zhang, Z.; Han, S.; Wang, X.; Chang, Y.; Bai, H.; et al. Preparation and evaluation of chitosan-polyvinyl alcohol/polyhexamethylene guanidine hydrochloride antibacterial dressing to accelerate wound healing for infectious skin repair. Ann. Transl. Med. 2021, 9, 482. [CrossRef]

147. Gould, L.J. Topical Collagen-Based Biomaterials for Chronic Wounds: Rationale and Clinical Application. Adv. Wound Care 2016, 5, 19-31. [CrossRef]

148. Talebian, S.; Rodrigues, T.; das Neves, J.; Sarmento, B.; Langer, R.; Conde, J. Facts and Figures on Materials Science and Nanotechnology Progress and Investment. ACS Nano 2021, 15, 15940-15952. [CrossRef]

149. Kirichenko, A.K.; Bolshakov, I.N.; Ali-Rizal, A.E.; Vlasov, A.A. Morphological Study of Burn Wound Healing with the Use of Collagen-Chitosan Wound Dressing. Bull. Exp. Biol. Med. 2013, 154, 692-696. [CrossRef] [PubMed]

150. González Alaña, I.; Torrero López, J.V.; Martín Playá, P.; Gabilondo Zubizarreta, F.J. Combined use of negative pressure wound therapy and Integra ${ }^{\circledR}$ to treat complex defects in lower extremities after burns. Ann. Burns Fire Disasters 2013, 26, 90. [PubMed]

151. Wu, S.; Applewhite, A.J.; Niezgoda, J.; Snyder, R.; Shah, J.; Cullen, B.; Schultz, G.; Harrison, J.; Hill, R.; Howell, M.; et al. Oxidized Regenerated Cellulose/Collagen Dressings: Review of Evidence and Recommendations. Adv. Skin Wound Care 2017, $30, \mathrm{S1}$. [CrossRef] [PubMed]

152. Gottrup, F.; Cullen, B.M.; Karlsmark, T.; Bischoff-Mikkelsen, M.; Nisbet, L.; Gibson, M.C. Randomized controlled trial on collagen/oxidized regenerated cellulose/silver treatment. Wound Repair Regen. 2013, 21, 216-225. [CrossRef]

153. Colaço, H.B.; Shah, Z.; Back, D.; Davies, A.; Ajuied, A. (iv) Xenograft in orthopaedics. Orthop. Trauma 2015, 29, 253-260. [CrossRef]

154. Park, J.J.; Hershman, S.H. Updates in the use of bone grafts in the lumbar spine. Bull. NYU Hosp. Jt. Dis. 2013, $71,39-48$.

155. Kumar, S.S.D.; Rajendran, N.K.; Houreld, N.N.; Abrahamse, H. Recent advances on silver nanoparticle and biopolymer-based biomaterials for wound healing applications. Int. J. Biol. Macromol. 2018, 115, 165-175. [CrossRef]

156. Rodríguez-Abreu, C. Nanocolloids: Some Basic Concepts and Principles of Their Stabilization. In Nanocolloids: A Meeting Point for Scientists and Technologists; Elsevier: Amsterdam, The Netherlands, 2016; pp. 1-36. ISBN 9780128015780.

157. Ouyang, S.; Hu, X.; Zhou, Q.; Li, X.; Miao, X.; Zhou, R. Nanocolloids in Natural Water: Isolation, Characterization, and Toxicity. Environ. Sci. Technol. 2018, 52, 4850-4860. [CrossRef]

158. Kothamasu, P.; Kanumur, H.; Ravur, N.; Maddu, C.; Parasuramrajam, R.; Thangavel, S. Nanocapsules: The Weapons for Novel Drug Delivery Systems. Bioimpacts 2012, 2, 71. [CrossRef] 
159. Niska, K.; Zielinska, E.; Radomski, M.W.; Inkielewicz-Stepniak, I. Metal nanoparticles in dermatology and cosmetology: Interactions with human skin cells. Chem. Biol. Interact. 2018, 295, 38-51. [CrossRef]

160. Quartinello, F.; Tallian, C.; Auer, J.; Schön, H.; Vielnascher, R.; Weinberger, S.; Wieland, K.; Weihs, A.M.; Herrero-Rollett, A.; Lendl, B.; et al. Smart textiles in wound care: Functionalization of cotton/PET blends with antimicrobial nanocapsules. J. Mater. Chem. B 2019, 7, 6592-6603. [CrossRef] [PubMed]

161. Shi, D.; Guo, Z.; Bedford, N. Nanobiological Materials. In Nanomaterials and Devices; Shi, D., Guo, Z., Bedford, N., Eds.; William Andrew Publishing: Kansas City, MO, USA, 2015; pp. 215-253. ISBN 978-1-4557-7754-9.

162. Lotfalian, S.; Nematollahzadeh, A.; Ghasemi, S. Hierarchically structured protein-based hollow-nanospheres for drug delivery React. Funct. Polym. 2021, 160, 104821. [CrossRef]

163. Asfour, M.H.; Mohsen, A.M. Formulation and evaluation of $\mathrm{pH}$-sensitive rutin nanospheres against colon carcinoma using HCT-116 cell line. J. Adv. Res. 2018, 9, 17-26. [CrossRef] [PubMed]

164. García, M.C. Nano- and microparticles as drug carriers. In Engineering Drug Delivery Systems; Seyfoddin, A., Dezfooli, S.M., Greene, C.A., Eds.; Woodhead Publishing: Sawston, UK, 2020; pp. 71-110. ISBN 9780081025482.

165. Ostróżka-Cieślik, A.; Sarecka-Hujar, B. The Use of Nanotechnology in Modern Pharmacotherapy. In Multifunctional Systems for Combined Delivery, Biosensing and Diagnostics; Grumezescu, A.M., Ed.; Elsevier: Amsterdam, The Netherlands, 2017 ; pp. 139-158.

166. Güldiken, Ç.G.; Karaosmanoğlu, O.; Sivas, H.; Gerçel, H.F. ZnO microparticle-loaded chitosan/poly(vinyl alcohol)/acacia gum nanosphere-based nanocomposite thin film wound dressings for accelerated wound healing. J. Appl. Polym. Sci. 2020, $137,48445$. [CrossRef]

167. Müller, W.E.G.; Tolba, E.; Dorweiler, B.; Schröder, H.C.; Diehl-Seifert, B.; Wang, X. Electrospun bioactive mats enriched with Ca-polyphosphate/retinol nanospheres as potential wound dressing. Biochem. Biophys. Reports 2015, 3, 150-160. [CrossRef]

168. Chime, S.A.; Kenechukwu, F.C.; Attama, A.A. Nanoemulsions-Advances in Formulation, Characterization and Applications in Drug Delivery. In Application of Nanotechnology in Drug Delivery; InTech Open: London, UK, 2014. [CrossRef]

169. Mukherjee, P.K.; Harwansh, R.K.; Bhattacharyya, S. Bioavailability of Herbal Products: Approach Toward Improved Pharmacokinetics. In Evidence-Based Validation of Herbal Medicine; Mukherjee, P.K., Ed.; Elsevier: Amsterdam, The Netherlands, 2015; pp. 217-245. ISBN 9780128009963.

170. Aswathanarayan, J.B.; Vittal, R.R. Nanoemulsions and Their Potential Applications in Food Industry. Front. Sustain. Food Syst. 2019, 3, 95. [CrossRef]

171. Jaiswal, M.; Dudhe, R.; Sharma, P.K. Nanoemulsion: An advanced mode of drug delivery system. 3 Biotech 2015, 5, 123. [CrossRef]

172. Pradhan, M.; Parihar, A.K.; Singh, D.; Singh, M.R. Quality by design and formulation optimization using statistical tools for safe and efficient bioactive loading. In Advances and Avenues in the Development of Novel Carriers for Bioactives and Biological Agents; Singh, M.R., Singh, D., Kanwar, J.R., Chauhan, N.S., Eds.; Academic Press: Cambridge, MA, USA, 2020; pp. 555-594.

173. Alam, P.; Ansari, M.J.; Anwer, M.K.; Raish, M.; Kamal, Y.K.T.; Shakeel, F. Wound healing effects of nanoemulsion containing clove essential oil. Atrif. Cells Nanomed. Biotechnol. 2016, 45, 591-597. [CrossRef]

174. Manuja, A.; Kumar, B.; Kumar, R.; Chhabra, D.; Ghosh, M.; Manuja, M.; Brar, B.; Pal, Y.; Tripathi, B.N.; Prasad, M. Metal/metal oxide nanoparticles: Toxicity concerns associated with their physical state and remediation for biomedical applications. Toxicol. Reports 2021, 8, 1970-1978. [CrossRef]

175. Jaswal, T.; Gupta, J. A review on the toxicity of silver nanoparticles on human health. Mater. Today Proc. 2021. [CrossRef]

176. Ajdary, M.; Keyhanfar, F.; Moosavi, M.A.; Shabani, R.; Mehdizadeh, M.; Varma, R.S. Potential toxicity of nanoparticles on the reproductive system animal models: A review. J. Reprod. Immunol. 2021, 148, 103384. [CrossRef] [PubMed]

177. Cypriyana, P.J.; Saigeetha, S.; Angalene, J.L.A.; Samrot, A.V.; Kumar, S.; Ponniah, P.; Chakravarthi, S. Overview on toxicity of nanoparticles, it's mechanism, models used in toxicity studies and disposal methods - A review. Biocatal. Agric. Biotechnol. 2021, 36, 102117. [CrossRef]

178. Jamil, B.; Abbasi, R.; Abbasi, S.; Imran, M.; Khan, S.U.; Ihsan, A.; Javed, S.; Bokhari, H. Encapsulation of Cardamom Essential Oil in Chitosan Nano-composites: In-vitro Efficacy on Antibiotic-Resistant Bacterial Pathogens and Cytotoxicity Studies. Front. Microbiol. 2016, 7, 1580. [CrossRef] [PubMed]

179. Ferrari, M. Beyond drug delivery. Nat. Nanotechnol. 2008, 3, 131-132. [CrossRef]

180. Auffan, M.; Rose, J.; Wiesner, M.R.; Bottero, J.Y. Chemical stability of metallic nanoparticles: A parameter controlling their potential cellular toxicity in vitro. Environ. Pollut. 2009, 157, 1127-1133. [CrossRef]

181. Barroso, A.; Mestre, H.; Ascenso, A.; Simões, S.; Reis, C. Nanomaterials in wound healing: From material sciences to wound healing applications. Nano Sel. 2020, 1, 443-460. [CrossRef]

182. Cao, H.; Meng, F.; Liu, X. Antimicrobial activity of tantalum oxide coatings decorated with Ag nanoparticles. J. Vac. Sci. Technol. A Vac. Surf. Film. 2016, 34, 124906. [CrossRef]

183. Kwiatkowska, A.; Granicka, L.H.; Grzeczkowicz, A.; Stachowiak, R.; Bacal, P.; Sobczak, K.; Darowski, M.; Kozarski, M.; Bielecki, J. Gold nanoparticle-modified poly(vinyl chloride) surface with improved antimicrobial properties for medical devices. J. Biomed. Nanotechnol. 2018, 14, 922-932. [CrossRef]

184. Antonelli, M.; De Pascale, G.; Ranieri, V.M.; Pelaia, P.; Tufano, R.; Piazza, O.; Zangrillo, A.; Ferrario, A.; De Gaetano, A.; Guaglianone, E.; et al. Comparison of triple-lumen central venous catheters impregnated with silver nanoparticles (AgTive $\left.{ }^{\circledR}\right)$ vs conventional catheters in intensive care unit patients. J. Hosp. Infect. 2012, 82, 101-107. [CrossRef] 
185. Chen, Y.M.; Dai, A.P.; Shi, Y.; Liu, Z.J.; Gong, M.F.; Yin, X.B. Effectiveness of silver-impregnated central venous catheters for preventing catheter-related blood stream infections: A meta-analysis. Int. J. Infect. Dis. 2014, 29, 279-286. [CrossRef]

186. Ansari, M.A.; Khan, H.M.; Khan, A.A.; Ahmad, M.K.; Mahdi, A.A.; Pal, R.; Cameotra, S.S. Interaction of silver nanoparticles with Escherichia coli and their cell envelope biomolecules. J. Basic Microbiol. 2014, 54, 905-915. [CrossRef] [PubMed]

187. Singh, B.R.; Singh, B.N.; Singh, A.; Khan, W.; Naqvi, A.H.; Singh, H.B. Mycofabricated biosilver nanoparticles interrupt Pseudomonas aeruginosa quorum sensing systems. Sci. Rep. 2015, 5, 13719. [CrossRef] [PubMed]

188. Ortiz-Benítez, E.A.; Velázquez-Guadarrama, N.; Durán Figueroa, N.V.; Quezada, H.; Olivares-Trejo, J. de J. Antibacterial mechanism of gold nanoparticles on Streptococcus pneumoniae. Metallomics 2019, 11, 1265-1276. [CrossRef] [PubMed]

189. Kędziora, A.; Speruda, M.; Krzyżewska, E.; Rybka, J.; Łukowiak, A.; Bugla-Płoskońska, G. Similarities and Differences between Silver Ions and Silver in Nanoforms as Antibacterial Agents. Int. J. Mol. Sci. 2018, 19, 444. [CrossRef]

190. Barros, C.H.N.; Fulaz, S.; Stanisic, D.; Tasic, L. Biogenic nanosilver against multidrug-resistant bacteria (MDRB). Antibiotics 2018, 7, 69. [CrossRef]

191. Slavin, Y.N.; Asnis, J.; Häfeli, U.O.; Bach, H. Metal nanoparticles: Understanding the mechanisms behind antibacterial activity. J. Nanobiotechnology 2017, 15, 65. [CrossRef]

192. Mukha, I.P.; Eremenko, A.M.; Smirnova, N.P.; Mikhienkova, A.I.; Korchak, G.I.; Gorchev, V.F.; Chunikhin, A.Y. Antimicrobial activity of stable silver nanoparticles of a certain size. Appl. Biochem. Microbiol. 2013, 49, 199-206. [CrossRef]

193. Choi, O.; Hu, Z. Size dependent and reactive oxygen species related nanosilver toxicity to nitrifying bacteria. Environ. Sci. Technol. 2008, 42, 4583-4588. [CrossRef]

194. Jahnke, J.P.; Cornejo, J.A.; Sumner, J.J.; Schuler, A.J.; Atanassov, P.; Ista, L.K. Conjugated gold nanoparticles as a tool for probing the bacterial cell envelope: The case of Shewanella oneidensis MR-1. Biointerphases 2016, 11, 011003. [CrossRef]

195. Kumar, A.; Pandey, A.K.; Singh, S.S.; Shanker, R.; Dhawan, A. Engineered ZnO and TiO2 nanoparticles induce oxidative stress and DNA damage leading to reduced viability of Escherichia coli. Free Radic. Biol. Med. 2011, 51, 1872-1881. [CrossRef]

196. Morones, J.R.; Elechiguerra, J.L.; Camacho, A.; Holt, K.; Kouri, J.B.; Ramírez, J.T.; Yacaman, M.J. The bactericidal effect of silver nanoparticles. Nanotechnology 2005, 16, 2346-2353. [CrossRef] [PubMed]

197. McQuillan, J.S.; Shaw, A.M. Differential gene regulation in the Ag nanoparticle and Ag+-induced silver stress response in Escherichia coli: A full transcriptomic profile. Nanotoxicology 2014, 8, 177-184. [CrossRef] [PubMed]

198. Gurunathan, S.; Choi, Y.-J.; Kim, J.-H. Antibacterial Efficacy of Silver Nanoparticles on Endometritis Caused by Prevotella melaninogenica and Arcanobacterum pyogenes in Dairy Cattle. Int. J. Mol. Sci. 2018, 19, 1210. [CrossRef] [PubMed]

199. Marambio-Jones, C.; Hoek, E.M.V. A review of the antibacterial effects of silver nanomaterials and potential implications for human health and the environment. J. Nanoparticle Res. 2010, 12, 1531-1551. [CrossRef]

200. Durán, N.; Durán, M.; de Jesus, M.B.; Seabra, A.B.; Fávaro, W.J.; Nakazato, G. Silver nanoparticles: A new view on mechanistic aspects on antimicrobial activity. Nanomed. Nanotechnol. Biol. Med. 2016, 12, 789-799. [CrossRef] [PubMed]

201. Gurunathan, S.; Park, J.H.; Han, J.W.; Kim, J.H. Comparative assessment of the apoptotic potential of silver nanoparticles synthesized by Bacillus tequilensis and Calocybe indica in MDA-MB-231 human breast cancer cells: Targeting p53 for anticancer therapy. Int. J. Nanomedicine 2015, 10, 4203. [CrossRef] [PubMed]

202. Sonavane, G.; Tomoda, K.; Sano, A.; Ohshima, H.; Terada, H.; Makino, K. In vitro permeation of gold nanoparticles through rat skin and rat intestine: Effect of particle size. Colloids Surf. B Biointerfaces 2008, 65, 1-10. [CrossRef]

203. Baroli, B.; Ennas, M.G.; Loffredo, F.; Isola, M.; Pinna, R.; López-Quintela, M.A. Penetration of Metallic Nanoparticles in Human Full-Thickness Skin. J. Invest. Dermatol. 2007, 127, 1701-1712. [CrossRef]

204. Larese, F.F.; D’Agostin, F.; Crosera, M.; Adami, G.; Renzi, N.; Bovenzi, M.; Maina, G. Human skin penetration of silver nanoparticles through intact and damaged skin. Toxicology 2009, 255, 33-37. [CrossRef]

205. Liu, Z.; Wu, Y.; Guo, Z.; Liu, Y.; Shen, Y.; Zhou, P.; Lu, X. Effects of Internalized Gold Nanoparticles with Respect to Cytotoxicity and Invasion Activity in Lung Cancer Cells. PLoS ONE 2014, 9, e99175. [CrossRef]

206. Karlsson, H.L.; Cronholm, P.; Gustafsson, J.; Möller, L. Copper Oxide Nanoparticles Are Highly Toxic: A Comparison between Metal Oxide Nanoparticles and Carbon Nanotubes. Chem. Res. Toxicol. 2008, 21, 1726-1732. [CrossRef] [PubMed]

207. Fahmy, B.; Cormier, S.A. Copper oxide nanoparticles induce oxidative stress and cytotoxicity in airway epithelial cells. Toxicol. Vitr. 2009, 23, 1365-1371. [CrossRef] [PubMed]

208. Rodhe, Y.; Skoglund, S.; Odnevall Wallinder, I.; Potácová, Z.; Möller, L. Copper-based nanoparticles induce high toxicity in leukemic HL60 cells. Toxicol. Vitr. 2015, 29, 1711-1719. [CrossRef] [PubMed]

209. Zielinska, E.; Tukaj, C.; Radomski, M.W.; Inkielewicz-Stepniak, I. Molecular Mechanism of Silver Nanoparticles-Induced Human Osteoblast Cell Death: Protective Effect of Inducible Nitric Oxide Synthase Inhibitor. PLoS ONE 2016, 11, e0164137. [CrossRef]

210. Rosário, F.; Hoet, P.; Santos, C.; Oliveira, H. Death and cell cycle progression are differently conditioned by the AgNP size in osteoblast-like cells. Toxicology 2016, 368-369, 103-115. [CrossRef]

211. Albers, C.E.; Hofstetter, W.; Siebenrock, K.A.; Landmann, R.; Klenke, F.M. In vitro cytotoxicity of silver nanoparticles on osteoblasts and osteoclasts at antibacterial concentrations. Nanotoxicology 2013, 7, 30-36. [CrossRef]

212. Xie, H.; Wang, P.; Wu, J. Effect of exposure of osteoblast-like cells to low-dose silver nanoparticles: Uptake, retention and osteogenic activity. Artif. Cells Nanomed. Biotechnol. 2019, 47, 260-267. [CrossRef] 
213. Grzeczkowicz, A.; Drabik, M.; Lipko, A.; Bacal, P.; Kwiatkowska, A.; Kazimierczak, B.; Granicka, L.H. A Composite Membrane System with Gold Nanoparticles, Hydroxyapatite, and Fullerenol for Dual Interaction for Biomedical Purposes. Membranes 2021, 11, 565. [CrossRef]

214. Yang, J.; Chen, Y.; Zhao, L.; Feng, Z.; Peng, K.; Wei, A.; Wang, Y.; Tong, Z.; Cheng, B. Preparation of a chitosan/carboxymethyl chitosan/AgNPs polyelectrolyte composite physical hydrogel with self-healing ability, antibacterial properties, and good biosafety simultaneously, and its application as a wound dressing. Compos. Part B Eng. 2020, 197, 108139. [CrossRef]

215. You, C.; Li, Q.; Wang, X.; Wu, P.; Ho, J.K.; Jin, R.; Zhang, L.; Shao, H.; Han, C. Silver nanoparticle loaded collagen/chitosan scaffolds promote wound healing via regulating fibroblast migration and macrophage activation. Sci. Rep. 2017, 7, 10489. [CrossRef]

216. Saravanan, S.; Nethala, S.; Pattnaik, S.; Tripathi, A.; Moorthi, A.; Selvamurugan, N. Preparation, characterization and antimicrobial activity of a bio-composite scaffold containing chitosan/nano-hydroxyapatite/nano-silver for bone tissue engineering. Int. J. Biol. Macromol. 2011, 49, 188-193. [CrossRef] [PubMed]

217. Łapaj, Ł.; Woźniak, W.; Markuszewski, J. Osseointegration of hydroxyapatite coatings doped with silver nanoparticles: Scanning electron microscopy studies on a rabbit model. Folia Morphol. 2019, 78, 107-113. [CrossRef] [PubMed]

218. Larkin Mchugh, G.; Moellering, R.C.; Hopkins, C.C.; Swartz, M.N. SALMONELLA TYPHIMURIUM RESISTANT TO SILVER NITRATE, CHLORAMPHENICOL, AND AMPICILLIN: A New Threat in Burn Units? Lancet 1975, 305, 235-240. [CrossRef]

219. Deshpande, L.M.; Chopade, B.A. Plasmid mediated silver resistance in Acinetobacter baumannii. Biometals 1994, 7, 49-56. [CrossRef]

220. Hendry, A.T.; Stewart, I.O. Silver-resistant Enterobacteriaceae from hospital patients. Can. J. Microbiol. 1979, $25,915-921$. [CrossRef]

221. Haefeli, C.; Franklin, C.; Hardy, K. Plasmid-determined silver resistance in Pseudomonas stutzeri isolated from a silver mine. J. Bacteriol. 1984, 158, 389-392. [CrossRef]

222. Murphy, P.S.; Evans, G.R.D. Advances in Wound Healing: A Review of Current Wound Healing Products. Plast. Surg. Int. 2012, 2012, 190436. [CrossRef]

223. McNeilly, O.; Mann, R.; Hamidian, M.; Gunawan, C. Emerging Concern for Silver Nanoparticle Resistance in Acinetobacter baumannii and Other Bacteria. Front. Microbiol. 2021, 12, 652863. [CrossRef] 